Prepared in cooperation with the Schuyler County Soil and Water Conservation District

\title{
Geohydrology of the Unconsolidated Valley-Fill Aquifer in the Meads Creek Valley, Schuyler and Steuben Counties, New York
}

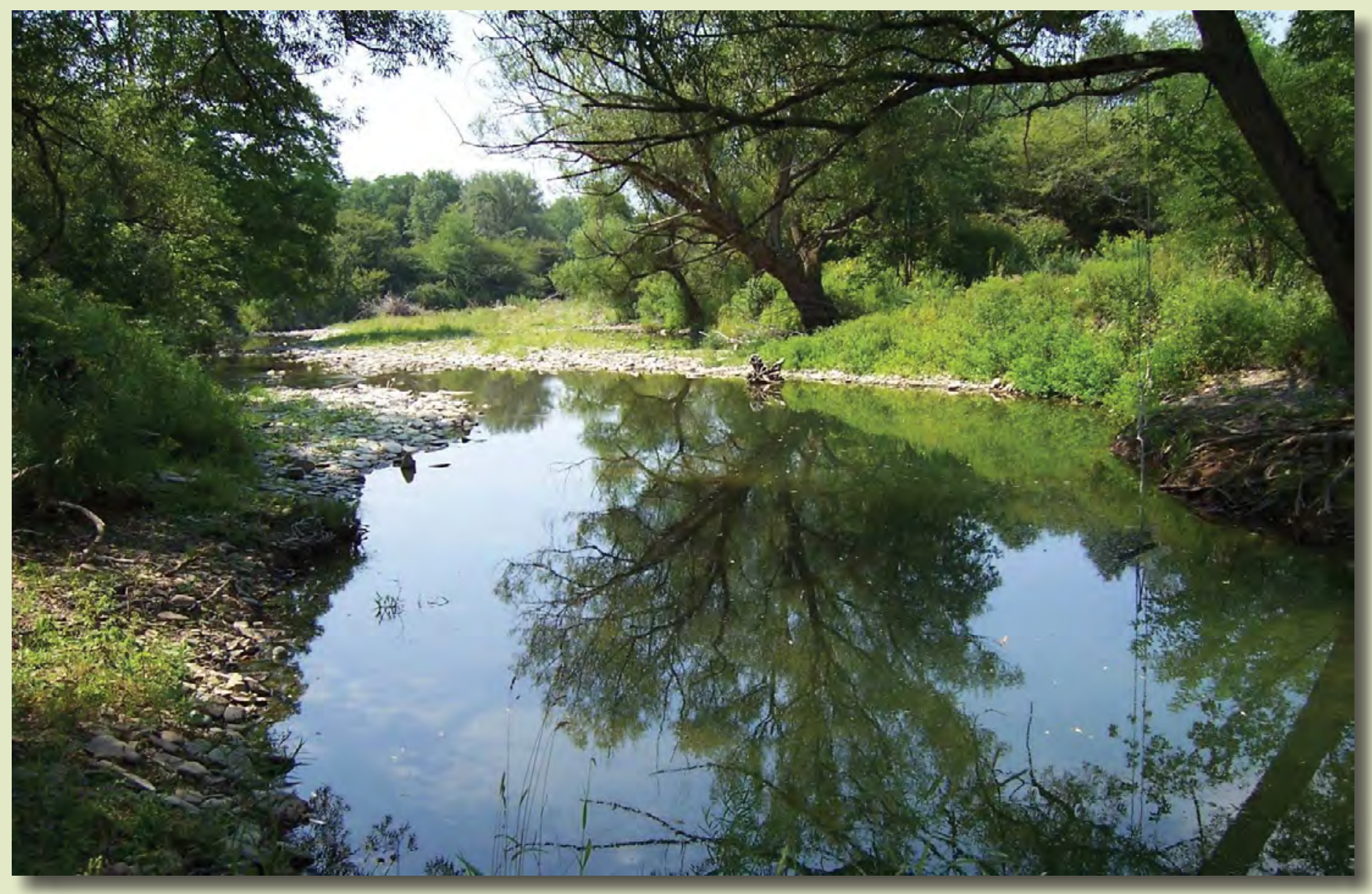

Scientific Investigations Report 2008-5122 
Cover. Upper reach of Meads Creek, Aug. 16, 2007. Photo courtesy Elaine Dalrymple. 


\section{Geohydrology of the Unconsolidated Valley-Fill Aquifer in the Meads Creek Valley, Schuyler and Steuben Counties, New York}

By Todd S. Miller, Edward F. Bugliosi, and James E. Reddy

Prepared in cooperation with the

Schuyler County Soil and Water Conservation District

Scientific Investigations Report 2008-5122 


\title{
U.S. Department of the Interior DIRK KEMPTHORNE, Secretary
}

\author{
U.S. Geological Survey \\ Mark D. Myers, Director
}

U.S. Geological Survey, Reston, Virginia: 2008

For more information on the USGS--the Federal source for science about the Earth, its natural and living resources, natural hazards, and the environment:

World Wide Web: http://www.usgs.gov

Telephone: 1-888-ASK-USGS

Any use of trade, product, or firm names is for descriptive purposes only and does not imply endorsement by the U.S. Government.

Although this report is in the public domain, permission must be secured from the individual copyright owners to reproduce any copyrighted materials contained within this report.

Suggested citation:

Miller, T.S., Bugliosi, E.F., and Reddy, J.E., 2008, Geohydrology of the unconsolidated valley-fill aquifer in the Meads Creek valley, Schuyler and Steuben Counties, New York: U.S. Geological Survey Scientific Investigations Report 2008-5122, 32 p, online only. 


\section{Contents}

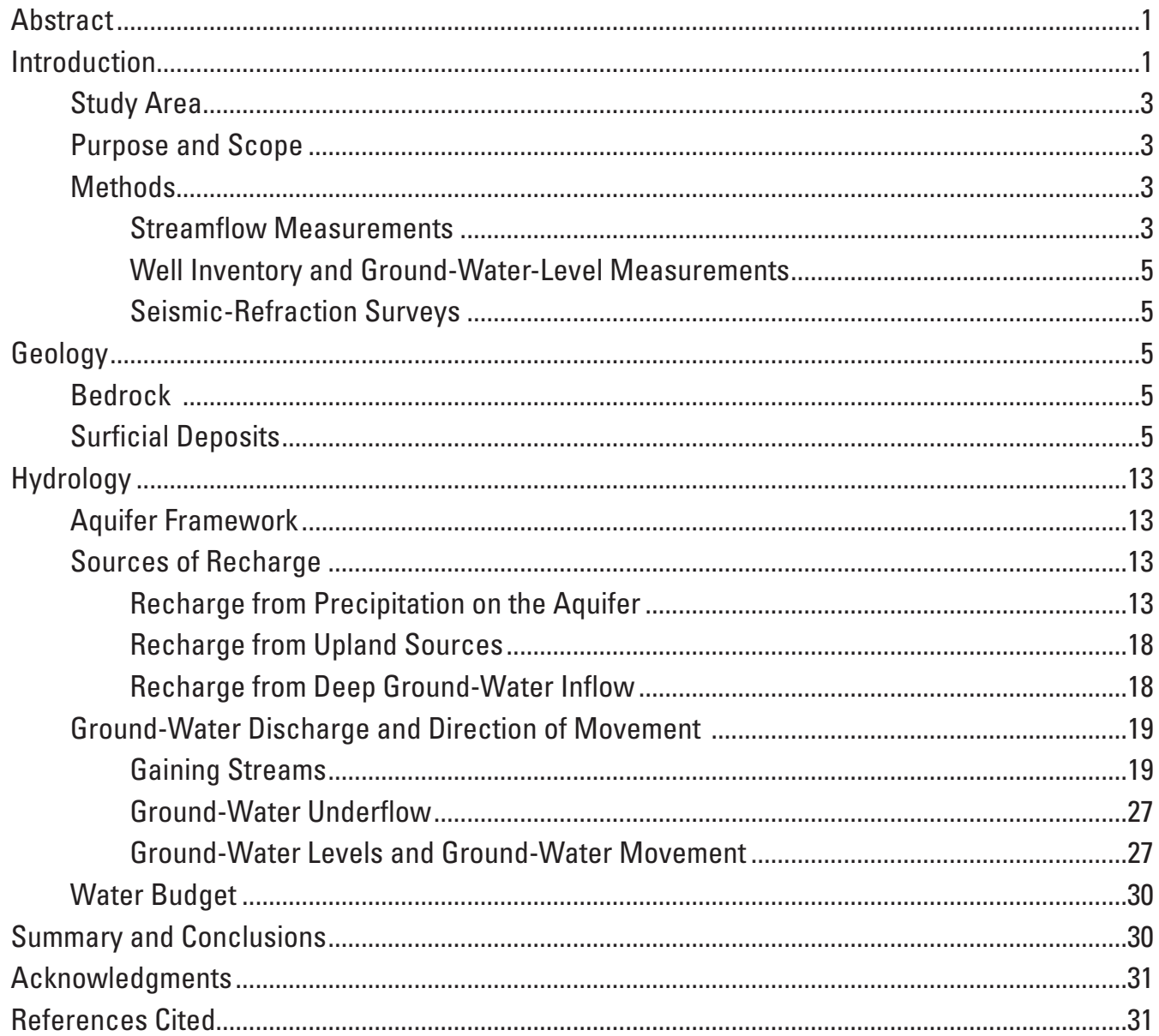

\section{Figures}

1. Map showing principal streams within Meads Creek basin in Schuyler and Steuben Counties, N.Y., and locations of valley-fill aquifer and of 2006 seismic-refraction surveys

2. Hydrograph of well SB 472 (site 422445077203301 ) near Kanona, N.Y., showing ground-water levels from October 2005 through October 2007, median groundwater level, and the periods during which streamflow and water-level measurements were made

3-5. Maps showing -

3. Locations of wells in which water levels were measured on June 1,2, and 5, 2007, in Meads Creek valley, Schuyler and Steuben Counties, N.Y................7

4. Bedrock geology of the Meads Creek basin, Schuyler and Steuben Counties, N.Y.

5. Surficial geology of the Meads Creek basin, Schuyler and Steuben Counties, N.Y. 
6-7. Diagrams showing-

6. (A) Vertical section A-A' across Chambers Road near northern end of Meads Creek valley in the town of Orange, Schuyler County, N.Y., and map showing details of seismic-survey line, and $(B)$ Vertical section $B-B^{\prime}$ in the town of Campbell, near southern end of Meads Creek valley in Steuben County, N.Y., and map showing details of seismic-survey line...

7. Sources of recharge to, and discharge from, valley-fill aquifers in the glaciated Northeast.

8-10. Maps showing-

8. Discharge measurements for identification of gaining and losing reaches along Meads Creek and seven tributaries, Schuyler and Steuben Counties, N.Y., April 27, 2006.

9. Areas of unchanneled hillsides adjacent to the valley-fill aquifer that contribute recharge directly to the aquifer in the Meads Creek valley, Schuyler and Steuben Counties, N.Y.

10. Potentiometric surface in the Meads Creek valley-fill aquifer, June 1-5, 2007, Schuyler and Steuben Counties, N.Y.

Tables

1. Water-level measurements in wells screened mostly in valley-fill aquifer in Meads Creek valley, Schuyler and Steuben Counties, N.Y., June 1-5, 2007

2. Water budget for Meads Creek valley-fill aquifer in Schuyler and Steuben Counties, N.Y., based on water-budget components and measured ground-water discharge to main channel of creek, April 27, 2006

3. Measured and estimated gaining and losing reaches along Meads Creek and selected tributaries on April 27, 2006, in Meads Creek valley, Schuyler and Stuben counties, N.Y. 


\section{Conversion Factors and Datums}

\begin{tabular}{|c|c|c|}
\hline Multiply & By & To obtain \\
\hline \multicolumn{3}{|c|}{ Length } \\
\hline inch (in.) & 2.54 & centimeter $(\mathrm{cm})$ \\
\hline inch (in.) & 25.4 & millimeter $(\mathrm{mm})$ \\
\hline foot $(\mathrm{ft})$ & 0.3048 & meter $(\mathrm{m})$ \\
\hline mile (mi) & 1.609 & kilometer $(\mathrm{km})$ \\
\hline \multicolumn{3}{|c|}{ Area } \\
\hline square foot $\left(\mathrm{ft}^{2}\right)$ & 0.09290 & square meter $\left(\mathrm{m}^{2}\right)$ \\
\hline square mile $\left(\mathrm{mi}^{2}\right)$ & 2.590 & square kilometer $\left(\mathrm{km}^{2}\right)$ \\
\hline \multicolumn{3}{|c|}{ Volume } \\
\hline cubic foot per year $\left(\mathrm{ft}^{3} / \mathrm{yr}\right)$ & 0.02832 & cubic meter per year $\left(\mathrm{m}^{3} / \mathrm{yr}\right)$ \\
\hline square foot per day $\left(\mathrm{ft}^{2} / \mathrm{d}\right)$ & 0.09290 & square meter per day $\left(\mathrm{m}^{2} / \mathrm{d}\right)$ \\
\hline \multicolumn{3}{|c|}{ Flow rate } \\
\hline foot per day (ft/d) & 0.3048 & meter per day $(\mathrm{m} / \mathrm{d})$ \\
\hline cubic foot per second $\left(\mathrm{ft}^{3} / \mathrm{s}\right)$ & 0.02832 & cubic meter per second $\left(\mathrm{m}^{3} / \mathrm{s}\right)$ \\
\hline $\begin{array}{l}\text { cubic foot per second per square mile } \\
{\left[\left(\mathrm{ft}^{3} / \mathrm{s}\right) / \mathrm{mi}^{2}\right]}\end{array}$ & 0.01093 & $\begin{array}{l}\text { cubic meter per second per square } \\
\text { kilometer }\left[\left(\mathrm{m}^{3} / \mathrm{s}\right) / \mathrm{km}^{2}\right]\end{array}$ \\
\hline cubic foot per day $\left(\mathrm{ft}^{3} / \mathrm{d}\right)$ & 0.02832 & cubic meter per day $\left(\mathrm{m}^{3} / \mathrm{d}\right)$ \\
\hline gallon per day (gal/d) & 0.003785 & cubic meter per day $\left(\mathrm{m}^{3} / \mathrm{d}\right)$ \\
\hline gallon per minute (gal/min) & 0.06309 & liter per second $(\mathrm{L} / \mathrm{s})$ \\
\hline $\begin{array}{l}\text { gallon per day per square mile }[(\mathrm{gal} / \mathrm{d}) / \\
\left.\mathrm{mi}^{2}\right]\end{array}$ & 0.001461 & $\begin{array}{l}\text { cubic meter per day per square } \\
\text { kilometer }\left[\left(\mathrm{m}^{3} / \mathrm{d}\right) / \mathrm{km}^{2}\right]\end{array}$ \\
\hline million gallons per day (Mgal/d) & 0.04381 & cubic meter per second $\left(\mathrm{m}^{3} / \mathrm{s}\right)$ \\
\hline
\end{tabular}

\begin{tabular}{lcc}
\hline \multicolumn{3}{c}{ Hydraulic conductivity } \\
\hline foot per day $(\mathrm{ft} / \mathrm{d})$ & 0.3048 & meter per day $(\mathrm{m} / \mathrm{d})$ \\
\hline & Hydraulic gradient & \\
\hline foot per mile $(\mathrm{ft} / \mathrm{mi})$ & 0.1894 & meter per kilometer $(\mathrm{m} / \mathrm{km})$ \\
\hline
\end{tabular}

Vertical coordinate information is referenced to the North American Vertical Datum of 1988 (NAVD 88).

Horizontal coordinate information is referenced to the North American Datum of 1983 (NAD 83).

Altitude, as used in this report, refers to distance above the vertical datum. 
This page has been left blank intentionally. 


\title{
Geohydrology of the Unconsolidated Valley-Fill Aquifer in the Meads Creek Valley, Schuyler and Steuben Counties, New York
}

\author{
By Todd S. Miller, Edward F. Bugliosi, and James E. Reddy
}

\section{Abstract}

The Meads Creek valley encompasses 70 square miles of predominantly forested uplands in the upper Susquehanna River drainage basin. The valley, which was listed as a Priority Waterbody by the New York State Department of Environmental Conservation in 2004, is prone to periodic flooding, mostly in its downstream end, where development is occurring most rapidly.

Hydraulic characteristics of the unconsolidated valleyfill aquifer were evaluated, and seepage rates in losing and gaining tributaries were calculated or estimated, in an effort to delineate the aquifer geometry and identify the factors that contribute to flooding. Results indicated that (1) Meads Creek gained about 61 cubic feet of flow per second (about 6.0 cubic feet per second per mile of stream channel) from ground-water discharge and inflow from tributaries in its 10.2-mile reach between the northernmost and southernmost measurement sites; (2) major tributaries in the northern part of the valley are not significant sources of recharge to the aquifer; and (3) major tributaries in the central and southern part of the valley provide recharge to the aquifer. The groundwater portion of streamflow in Meads Creek (excluding tributary inflow) was 11.3 cubic feet per second $\left(\mathrm{ft}^{3} / \mathrm{s}\right)$ in the central part of the valley and $17.2 \mathrm{ft}^{3} / \mathrm{s}$ in the southern part-a total of $28.5 \mathrm{ft}^{3} / \mathrm{s}$.

Ground-water levels were measured in 29 wells finished in unconfined deposits for construction of a potentiometricsurface map to depict directions of ground-water flow within the valley. In general, ground water flows from the edges of the valley toward Meads Creek and ultimately discharges to it. The horizontal hydraulic gradient for the entire 12-mile-long aquifer averages about 30 feet per mile, whereas the gradient in the southern fourth of the valley averages about half that-about 17 feet per mile.

A water budget for the aquifer indicated that 28 percent of recharge was derived from precipitation that falls on the aquifer, 32 percent was from losing reaches of tributaries, 38 percent was unchanneled flow from hillsides that slope toward the valley (this estimate includes runoff and shallow ground-water inflow from till and bedrock), and the remaining 2 percent was from deep ground-water inflow from till and bedrock to the sides and bottom of the aquifer. Nearly all (94 percent) of the water discharged from the aquifer is equivalent to the streamflow gain in Meads Creek; the remaining 6 percent discharges as deep outflow to unconsolidated deposits in the Cohocton River valley.

Several characteristics of the Meads Creek valley may contribute to flooding in the downstream area: (1) the southward decrease in the ground-water gradient impedes the ability of the aquifer to transmit water southward and can cause water levels to rise, (2) a high water table, typically only 5 to 10 feet below land surface, results in little storage capacity to absorb water from large storms, (3) a downstream narrowing of the valley impedes the southward flow of ground water and can cause water levels to rapidly rise during periods of prolonged or heavy precipitation, and (4) the upland slopes (till-covered bedrock) produce rapid runoff that recharges the aquifer. The combined effect of these conditions limits the ability of the aquifer to transmit sudden, large increases in recharge from precipitation and thereby provides a high potential for flooding in the southern third of the valley.

\section{Introduction}

The valley-fill aquifer in the Meads Creek valley in south-central New York (fig. 1) is the sole source of water to the majority of residents and several small businesses, but the valley itself is prone to frequent flooding in the southern area, where most of the recent development has occurred. The Steuben and Schuyler County Water Quality Coordinating Committees have ranked the $70 \mathrm{mi}^{2}$ Meads Creek basin (in this report the "Meads Creek basin" refers to the entire watershed that drains to Meads Creek, and "Meads Creek valley" refers only to the relatively flat low-lying valley floor and underlying valley-fill deposts underlying the main channel of Meads Creek) as a "high priority" for restoration of water quality and natural resources and land-use protection, based on relationships between population densities, land-use laws and 


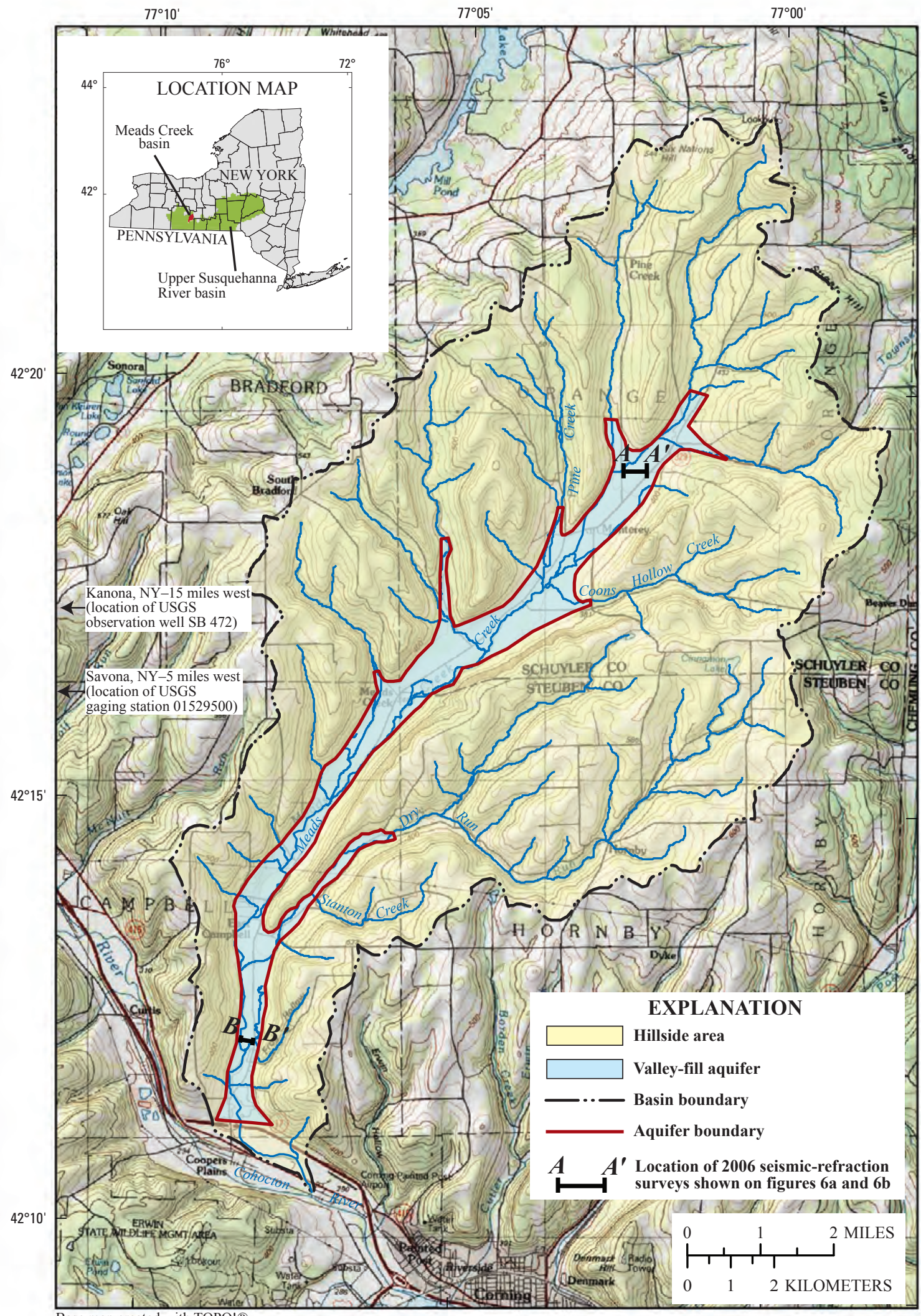

Base map created with TOPO!®

C 2003 National Geographic (www.nationalgeographic.com/topo)

Figure 1. Principal streams within Meads Creek basin in Schuyler and Steuben Counties, N.Y., and locations of valley-fill aquifer and of 2006 seismic-refraction surveys. 
topography (Meads Creek Watershed Citizens' Committee, 2007), and the New York State Department of Environmental Conservation (NYSDEC) included Meads Creek on the 1998 and 2004 "Priority Waterbodies List" (PWL), which indicates an inability to support designated uses such as recreation or to support aquatic life.

Hydrologic information, such as the locations and rate of aquifer recharge, is needed to enable local agencies to develop water-management strategies that can be used to understand and help mitigate the flood hazard. Data that are specifically needed include (1) aquifer geometry, (2) locations of aquiferrecharge and discharge areas, (3) directions of ground-water flow, (4) hydraulic properties of aquifer units, and (5) extent of exchange between ground water and surface water. Several agencies in the Meads Creek valley, including the towns of Orange (Schuyler County), Campbell, and Hornby (Steuben County); County Soil and Water Conservation Districts; Schuyler and Steuben County Departments of Health, Planning, and Highways; and the New York State Departments of Environmental Conservation and Health, require hydrogeologic information on the aquifer system to manage this water resource and develop plans to minimize damage from periodic flooding.

\section{Study Area}

Meads Creek drains $70 \mathrm{mi}^{2}$ within the upper Susquehanna River basin and is a tributary to the Cohocton River (fig. 1). The Meads Creek basin is predominantly forested but contains some agricultural areas and dairy farms in its central and northern parts; the southern part contains moderate residential and commercial development. About 80 percent of the upland area is owned by the State of New York and is managed as State forest and recreation area (Meads Creek Watershed Citizens' Committee, 2007). Average annual precipitation ranges from 32 to $34 \mathrm{in}$., averaging $33 \mathrm{in.}$ (Randall, 1996).

The Meads Creek valley (for the purposes of this report, the valley is considered the relatively flat valley floor of Meads Creek, including the flatter part of several major tributaries that extend partway up their sub-basins) is flanked by moderately to steeply sloping hillsides. Altitudes range from 950 the mouth of the valley to $2,000 \mathrm{ft}$ on the highest hilltop. The valley floor (fig. 1) is relatively flat and occupies about 10 percent of the valley; it consists mostly of coarse-grained alluvial deposits (Cadwell, 1986) that may be underlain locally by finer-grained glaciolacustrine (lake) deposits or coarser ice-contact deposits (kames and kame terraces). Streamflow is "flashy" (streams rise quickly and then recede back to their previous flow) because the hillsides, which consist of shale overlain by poorly permeable till, produce rapid runoff. Most development is on the valley floor, where flooding has increased in frequency and intensity in recent years (Elaine Dalrymple, Schuyler County Soil and Water Conservation District, oral commun., 2006). Locally, the rapid aggradation of streambeds has diminished the capacity of bridges to pass floodwater; aggredation also has been causing streams to overflow during heavy storms. Channel aggradation and flooding are an increasing threat to property, infrastructure, and residents (Elaine Dalrymple, Schuyler County Soil and Water Conservation District, oral commun., 2006).

In 2006, the U.S. Geological Survey (USGS), in cooperation with the Schuyler County Soil and Water Conservation District, began a 2-year study to characterize the aquifer, delineate the directions of ground-water movement, identify aquifer-recharge and discharge areas, measure the gains and losses of streamflow in Meads Creek and its major tributaries, and develop a water budget to provide information about the recharge to and discharge from the valley-fill aquifer. The aquifer areas of concern were the coarse-grained deposits that are at least $10 \mathrm{ft}$ thick in the main valley and in several tributary valleys. This study was designed as the data-collection phase of a proposed aquifer assessment that is to include construction of a ground-water-flow model of the aquifer system.

\section{Purpose and Scope}

This report presents the results of the data-collection phase of the study. It describes the approach and methods, characterizes the valley-fill deposits in and along the main stem and in major tributaries of Meads Creek, summarizes the surficial and bedrock geology of the basin, provides estimates of aquifer recharge and ground-water discharge to the valleyfill aquifer, includes a map that depicts the directions of ground-water movement within the aquifer, and presents a water budget for the aquifer.

\section{Methods}

Several types of data were collected to provide the basis for interpreting the hydrogeologic system in the Meads Creek basin and within the valley-fill aquifer. The field methodologies employed throughout this study followed USGS guidelines and technical manuals and all field data were collected by USGS personnel.

\section{Streamflow Measurements}

Streamflow measurements were made at 18 sites along the main valley, and on major tributaries, to quantify the amount of recharge entering and discharging from the valleyfill aquifer on April 27, 2006. This information was later used to compute a water budget representing the aquifer system during a period of average annual base flow and groundwater levels. Recharge that enters the aquifer consists of precipitation, stream loss from the major upland tributaries where they flow over the aquifer, and ground water that discharges into the main channel of Meads Creek from the 
underlying and adjacent till and bedrock. The streamflowmeasurement date was during a period that was inferred to represent average hydrologic conditions as indicated by water levels recorded in a USGS Climate Response Network observation well near Kanona, N.Y., about 12 mi west of the study area. This well (SB 472, site 422445077203301) is finished in unconsolidated deposits and has been used to record ground-water levels for the past 42 years, since 1965. Water levels in this well from October 2005 through October 2007 are plotted in figure 2 .

Streamflow measurements were made in the main channel of Meads Creek, and in selected accessible major tributaries, on April 27, 2006. The main purpose of these measurements was to identify which tributaries are losing streams (sources of aquifer recharge) and which are gaining streams (receiving discharge from the aquifer). To be meaningful, gains or losses must be greater in magnitude than the uncertainty associated with the measurements. Measurements on April 27, 2006, on Meads Creek were rated at + or -5 percent (10 percent total) of the measured flow, and the corresponding gains or losses were within 5 percent of the flows and within of the margin of error. The degree of surface-water exchange with ground water in tributaries varies within the basin; that is, some reaches may gain water while others may lose water. Fifteen measurements were made in the tributaries to document their gaining or losing status, and three were made in the main channel of Meads Creek. In addition, flow at the mouth of Meads Creek was assumed to be equal to the total base flow leaving the basin and was used in computing the water budget of the aquifer system.

The streamflow measurements were made when the water level in well SB 472 was about $8.5 \mathrm{ft}$ below land surface, which is slightly above the median annual groundwater level for the 42-year period of record ( $8.9 \mathrm{ft}$ below land surface, fig. 2). Discharge measurements were made with either a Standard Price AA or Pygmy current meter in accordance with USGS standards and methods (Rantz and others, 1982).

Additionally, the discharge record from the streamflowgaging station at Cohocton River near Campbell, N.Y. (01529500, fig. 1), which is about $5 \mathrm{mi}$ west of the Meads Creek valley, was inspected to verify that Meads Creek was

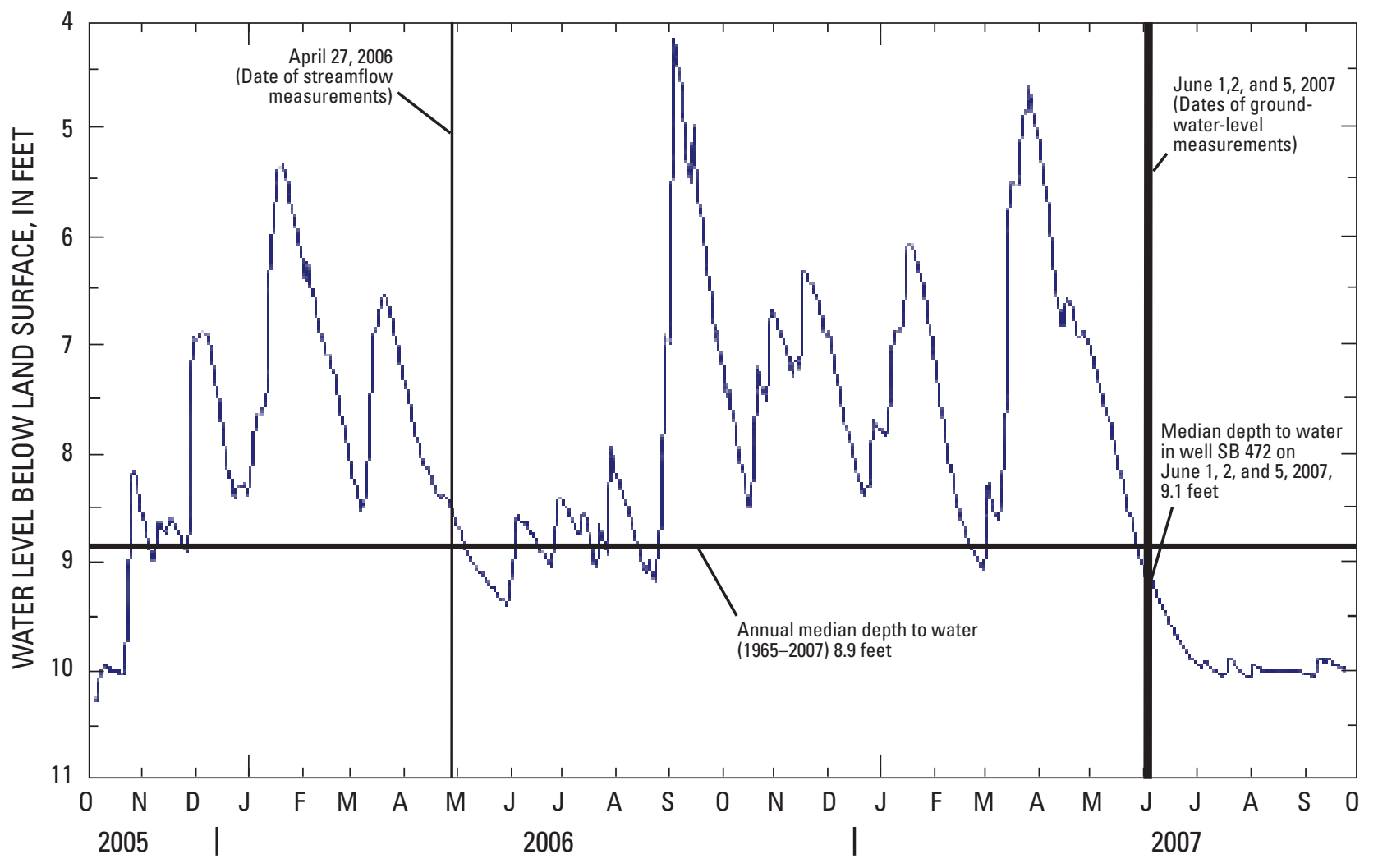

Figure 2. Hydrograph of well SB 472 (site 422445077203301) near Kanona, N.Y., showing ground-water levels from October 2005 through October 2007, median ground-water level, and the periods during which streamflow and water-level measurements were made. (Location is shown in fig. 1.) 
also near average base-flow conditions during the time of measurement. The Cohocton River gage is about $5 \mathrm{mi}$ west of the Meads Creek valley near Savona, N.Y. (fig. 1), and has 90 years of continuously recorded discharge data. Baseflow regression analysis (Sloto and Crouse, 1996) of the discharge record for this station indicated that the average base flow for the period of record at this site was about onethird less, or $258 \mathrm{ft}^{3} / \mathrm{s}$, than the discharge at this site on the day measurements were made on Meads Creek $\left(388 \mathrm{ft}^{3} / \mathrm{s}\right)$. Nevertheless, the date of the Meads Creek measurements was considered representative of long-term, average ground-waterlevel conditions, even if average base flow for the period of record at the Cohocton River gage was one-third less. The components of the resulting water budget were adjusted downward by 33 percent (multiplied by 0.67 ) to account for this difference.

\section{Well Inventory and Ground-Water- Level Measurements}

Well records were collected from several sources, including the USGS Ground-Water Site Inventory (GWSI) database, NYSDEC Water-Well Reporting Program, the Schuyler and Steuben County Health Departments, the Soil and Water Conservation Districts, and several Meads Creek Watershed-Protection Committee members. The most complete well records were provided by the NYSDEC WaterWell Reporting Program, which was implemented in 2000 to collect information on newly drilled wells in New York from licensed water-well drillers. These data included well location and depth, water level, sediment lithology, and pumping yield. The Schuyler and Steuben County Health Departments identified public-supply wells (at mobile home parks), and members of the Meads Creek Watershed-Protection Committee helped obtain permissions to measure water levels in wells of private homeowners.

Selected homeowners, commercial facilities, and institutions within the valley were sent a letter that described the project and requested permission to measure the water level in the well. The letter included a brief description of the objectives of the study, contact information for the USGS, and questions about the well and its construction. A copy of the data set was left with each well owner after water-level measurements were made.

Water levels were measured on June 1, 2, and 5, 2007, during a period that represents average annual ground-water conditions, from the highest point on the top of the casing (TOC) (fig. 3 and table 1). The data were recorded in the field, then collated into a spreadsheet that was then translated to a geographic information system (GIS) format. Landsurface altitudes at wells were derived from USGS 1:24,000 topographic maps and 10-meter digital elevation model (DEM) data sets (NAVD 88), the accuracy being + or - $5 \mathrm{ft}$. Adjustments for casing height above land surface were applied to obtain the altitude of the measuring points; the depths to water in the wells were then subtracted from the TOC altitude to obtain the ground-water level. The ground-water level was adjusted to the nearest foot.

\section{Seismic-Refraction Surveys}

No information on the thickness of unconsolidated valley-fill deposits in the Meads Creek valley was available; therefore, seismic-refraction surveys were conducted along two transects across the valley - one in the northern part, and one in the southern part (fig. 1). Geophones were spaced at optimum intervals for the estimated depth of the intended target (bedrock surface) and to receive adequate sound energy from shots, for which small explosives were used.

\section{Geology}

The southward draining Meads Creek valley is a result of millions of years of fluvial erosion that dissected uplifted Devonian-age sedimentary bedrock. The bedrock topography was modified by several glaciations during the Pleistocene era, which lasted from 1.6 million years to 10,000 years ago (Isachsen and others, 1991), and has subsequently been altered through recent stream erosion. The basin is defined by a drainage divide that follows bedrock ridges (fig. 1).

\section{Bedrock}

The bedrock underlying the Meads Creek valley is Upper Devonian-age siltstone, shale, and fine-grained sandstone and dips at about 3 degrees toward the south (Rickard and others, 1970). The units subcrop beneath overlying unconsolidated deposits (fig. 4). The bedrock is considered a low-yielding aquifer that typically produces only 3 to $5 \mathrm{gal} / \mathrm{min}$ to wells but can yield several tens of gallons per minute locally. The bedrock units have little primary permeability; therefore, most ground water moves through fractures. The bedrock aquifer yields enough water to supply homes, small farms, and commercial facilities.

\section{Surficial Deposits}

The northeastern United States was glaciated more than once; the most recent major glacial episode, termed the Wisconsinan, reached its maximum extent in most of eastern North America about 21,000 years ago (Mickelson and others, 1983; Stone, 1995). The most recent glaciation scoured most of the older sediment away; thus, most of the stratified sediment now present in valleys of the Northeast was deposited during the retreat of the last ice sheet, from 21,000 to 12,000 years ago, and through postglacial deposition of alluvial material by recent streams. The percentage of land surface in the Meads Creek basin that is mantled by sand and 


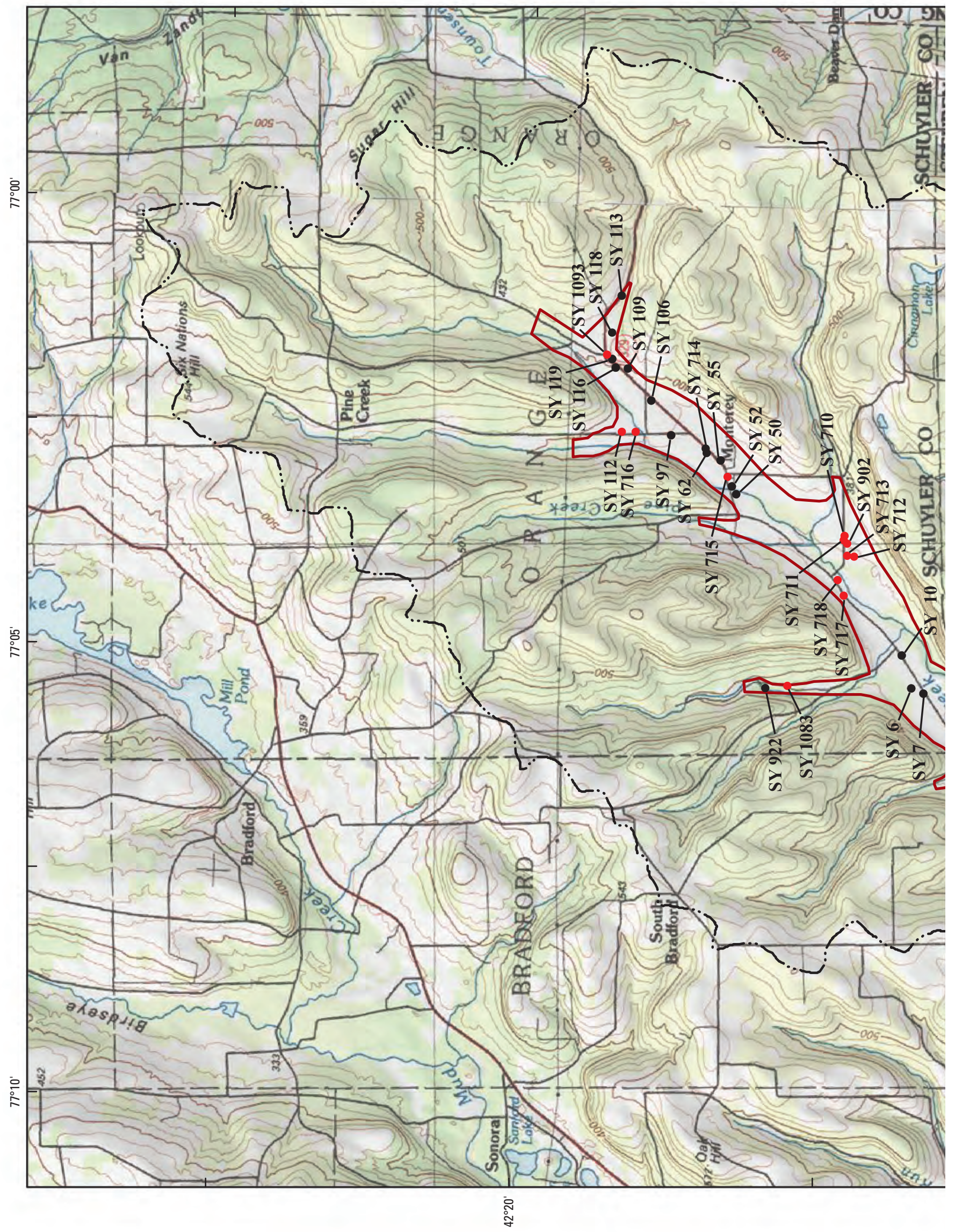




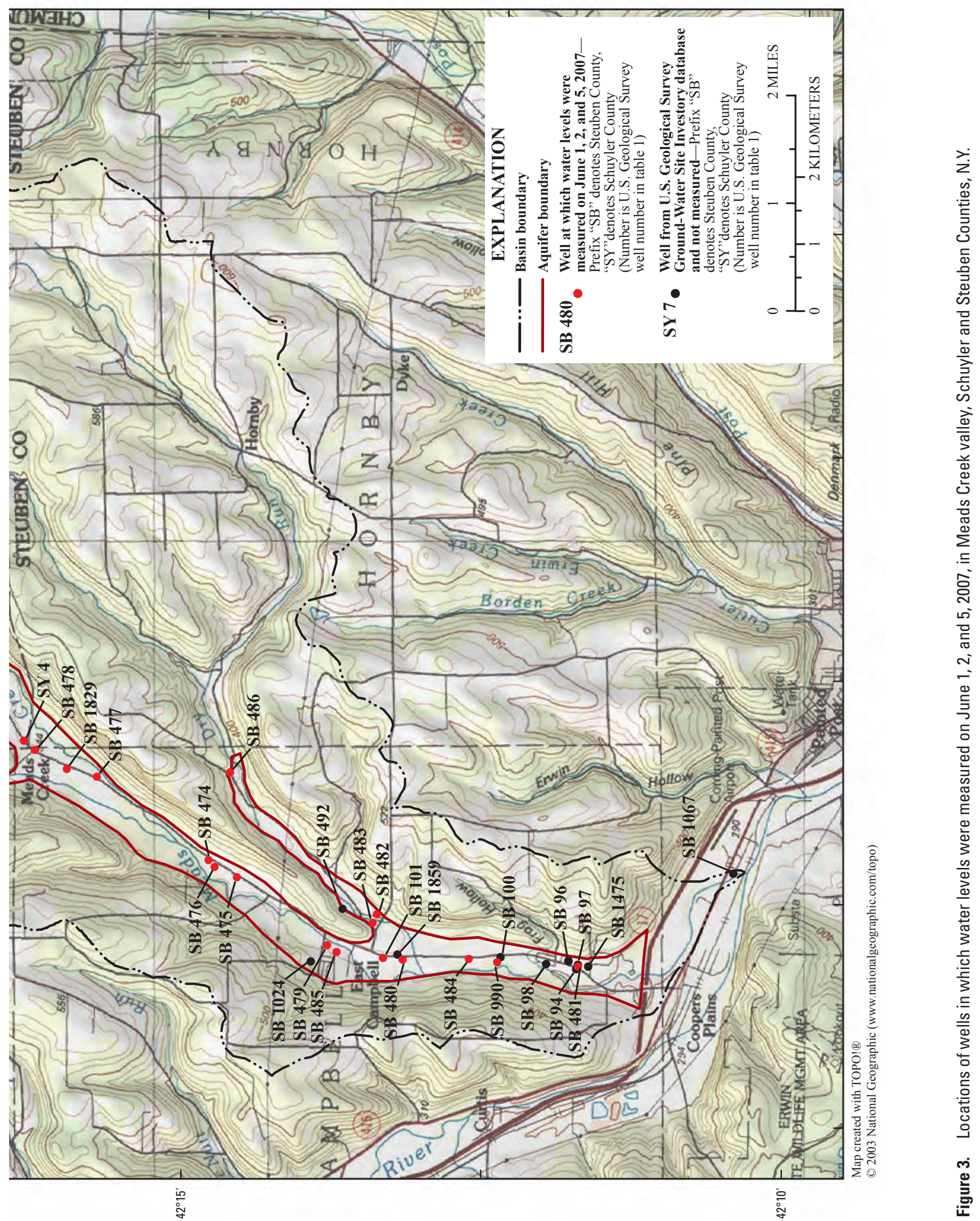




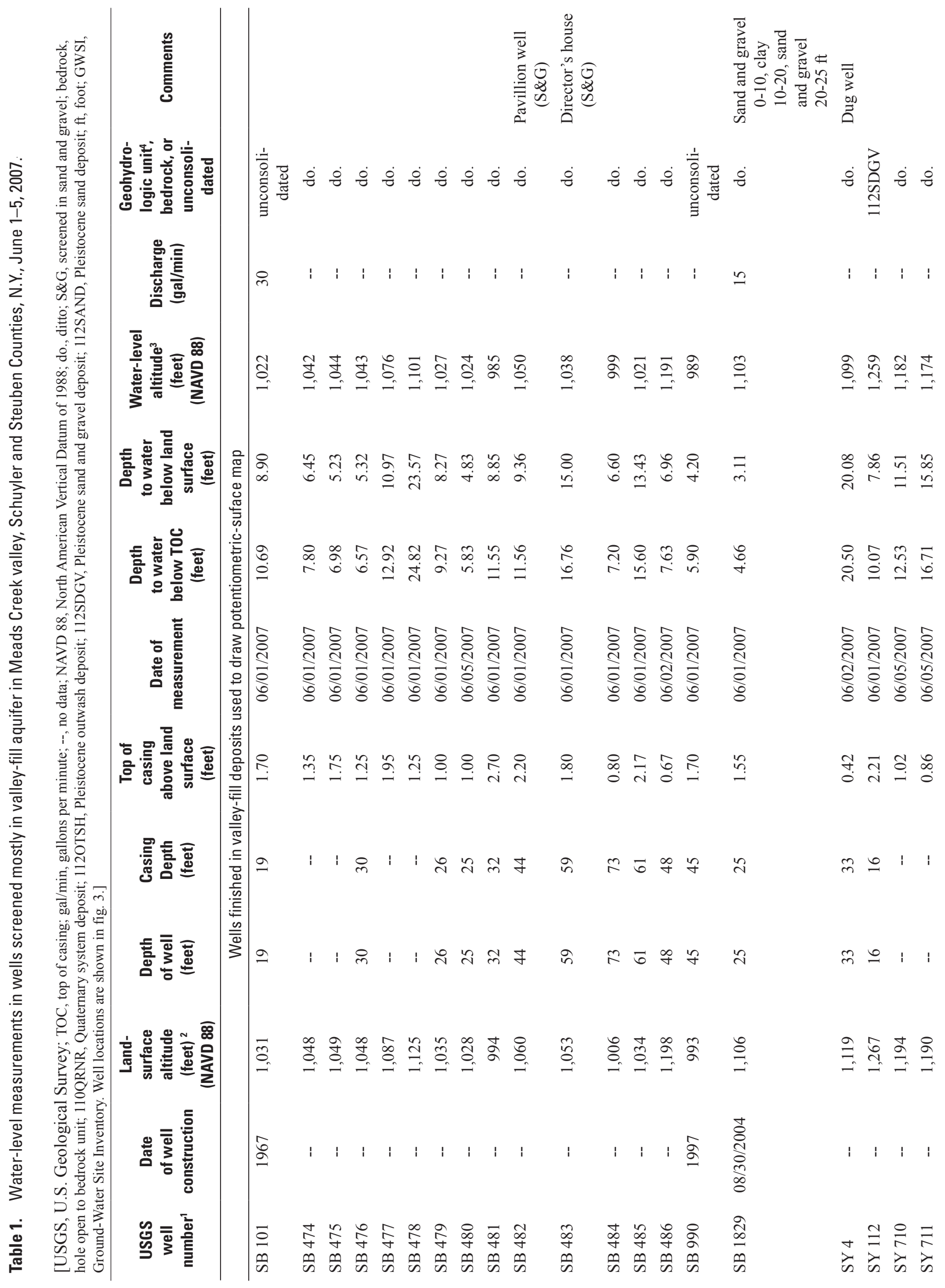




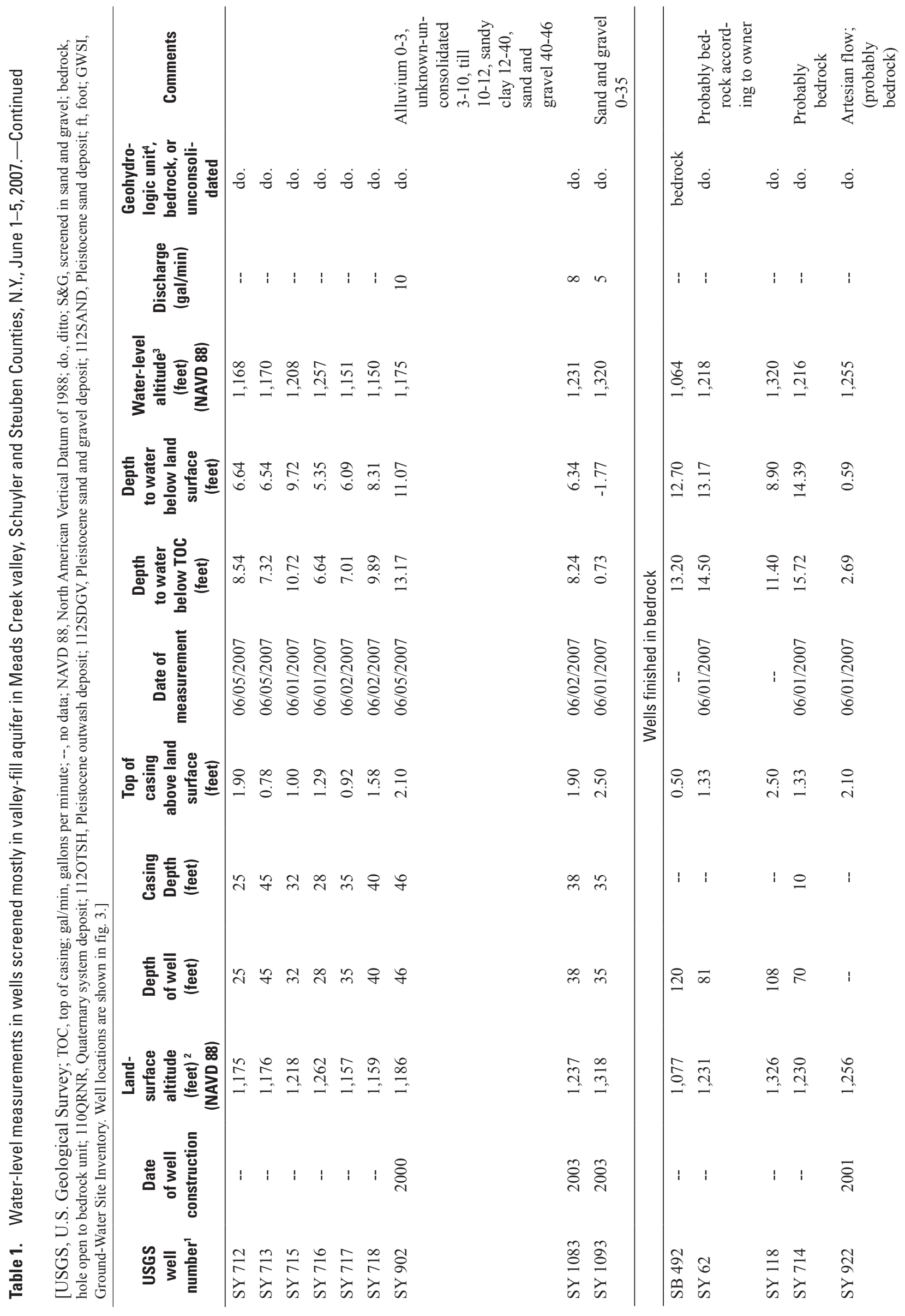




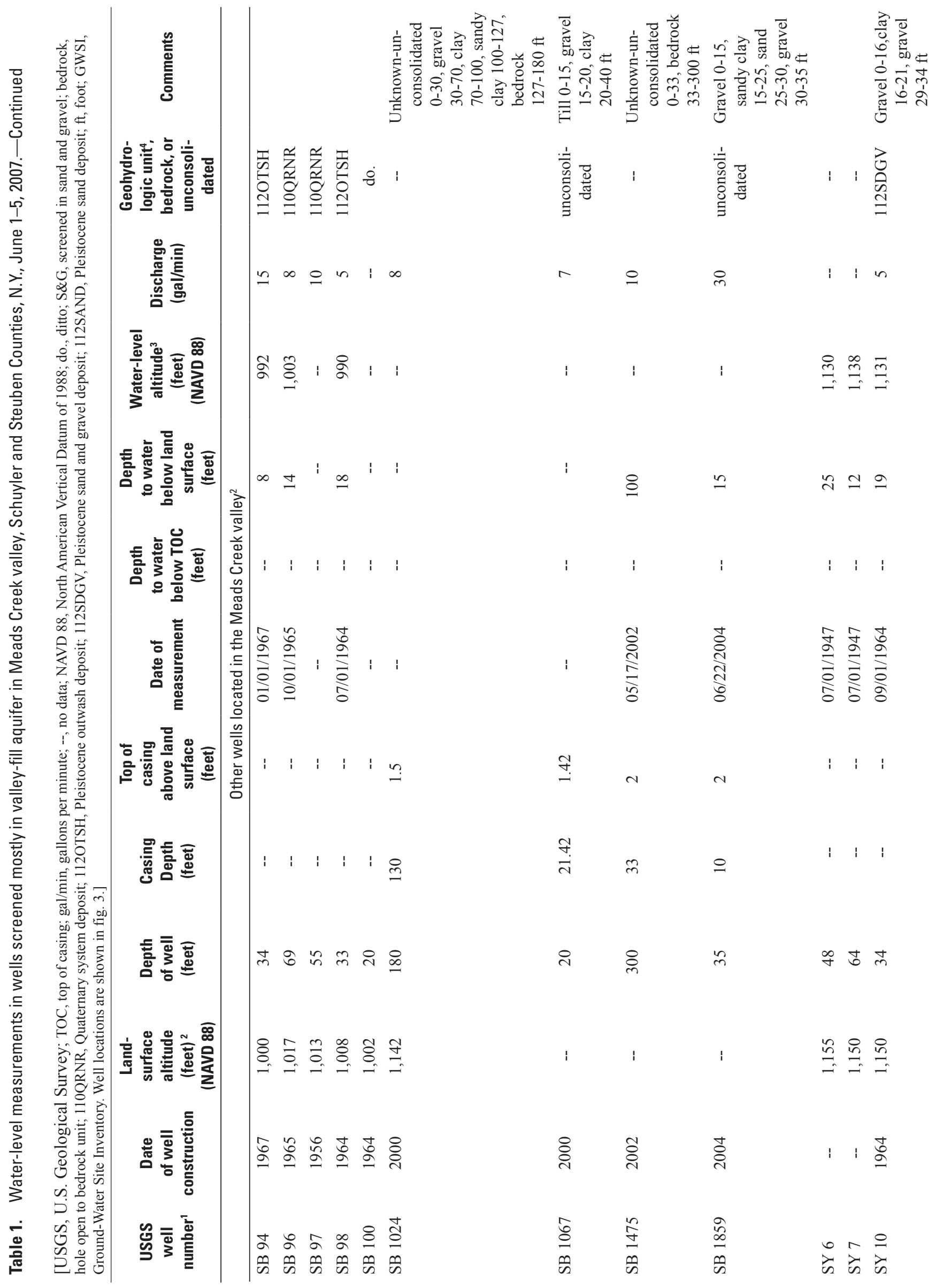




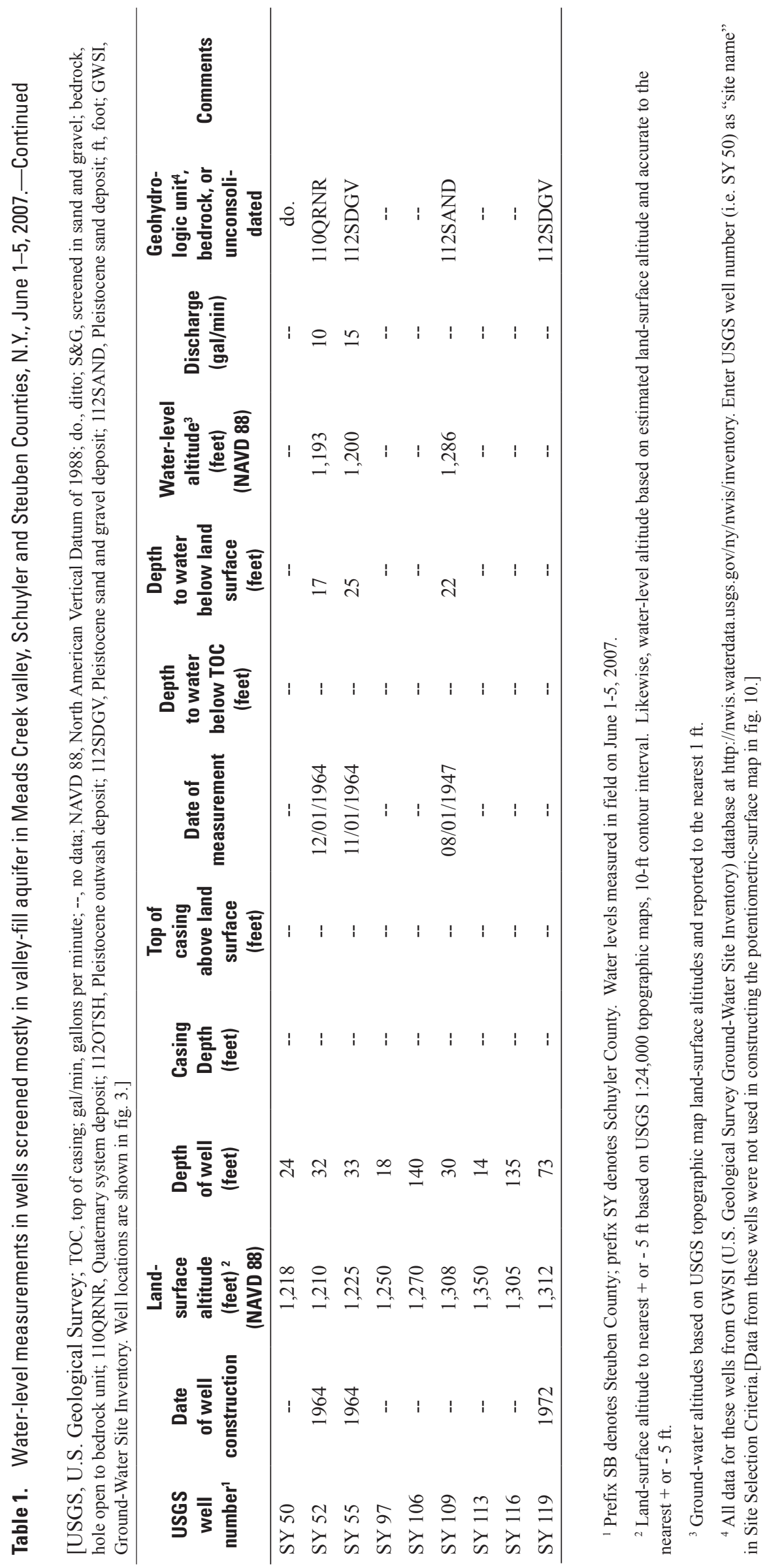




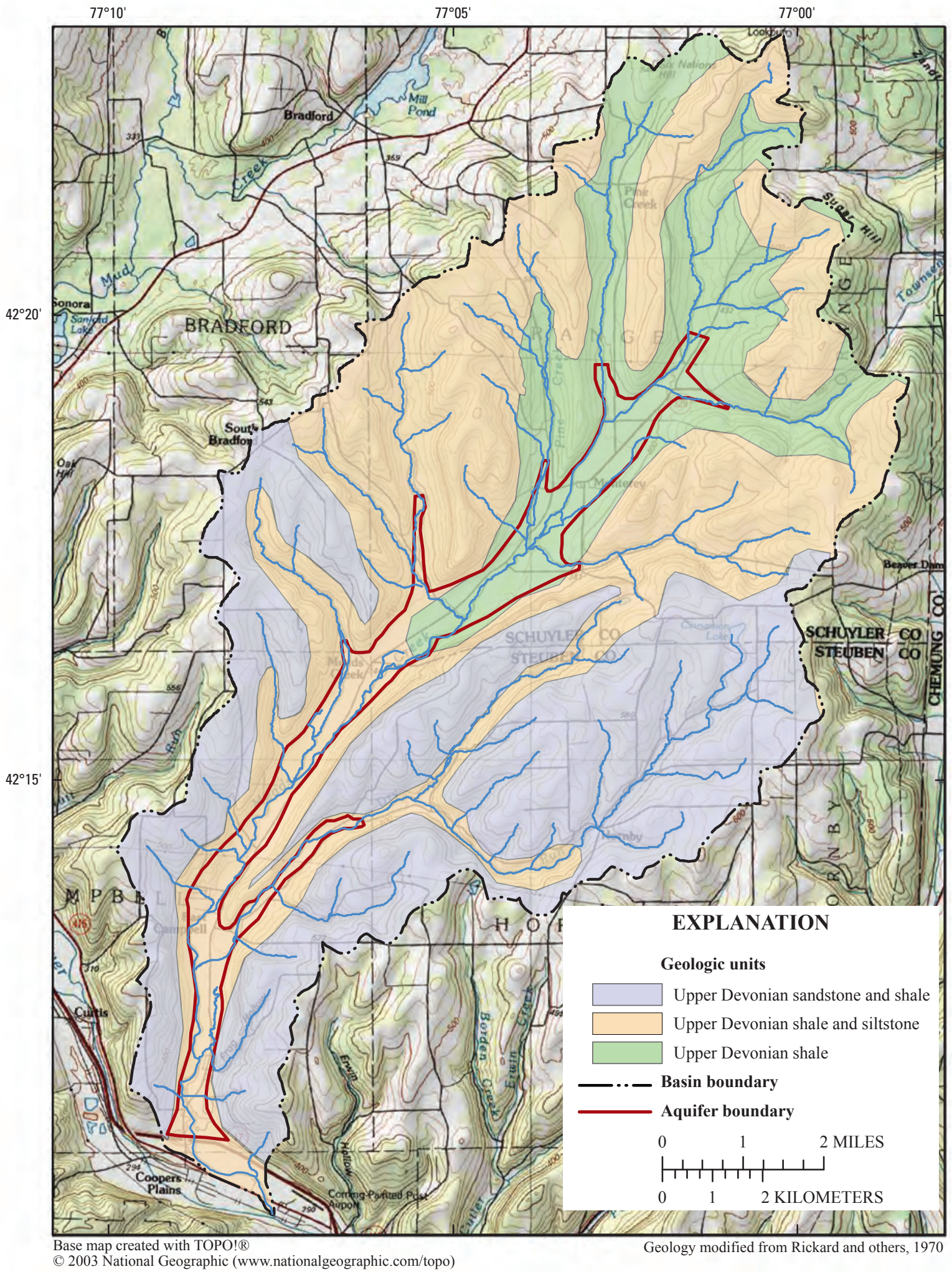

Figure 4. Bedrock geology of the Meads Creek basin, Schuyler and Steuben Counties, N.Y. 
gravel is relatively small-about 10 percent, according to the ratio of aquifer-surface area to the entire basin area - and consists mostly of post-glacial alluvial deposits and some minor amounts of glaciofluvial deposits such as kames (fig. 5).

Bedrock in the Meads Creek valley uplands is overlain by till and poorly sorted, unstratified, mixtures of sediment that can range in size from clay to boulders that was deposited beneath and compacted by glaciers: the weight and stress of the ice resulted in poor permeability. Till thickness within the Meads Creek basin typically ranges from 10 to $50 \mathrm{ft}$. Till normally can provide small amounts of water to largediameter dug wells, generally enough only for domestic use. Most of the unconsolidated deposits in the northern part of Meads Creek valley consist of post-glacial alluvium (fig. 5). Little is known about the types of deposits present in the deeper parts of the valley-fill material. At land surface, few, if any, large glaciofluvial deposits such as eskers, outwash, and kame ice-contact deposits are present because this valley does not contain a "through valley" (a preglacial low area between two valleys that could be breached and scoured by glaciers and that normally contains large amounts of glacial sediment as a result); instead, the Meads Creek basin has a high bedrock drainage divide to the north that inhibited the flow of ice and thereby prevented the vast accumulation of glacial material that is typically found in other "through valleys" in western and central New York.

Well records indicate that most of the upper part of the valley-fill material consists of sand and gravel and little or no fine-grained lake deposits (stratified fine sand, silt, and clay); little data are available to discern the types of sediment that compose the deeper parts of the valley fill. The total thickness of the valley-fill deposits in the Meads Creek valley is mostly unknown, except where the two seismic-refraction surveys were conducted for this study (fig. 1), because few wells in the Meads Creek valley extend to bedrock.

\section{Hydrology}

The valley-fill aquifer in Meads Creek valley consists of unconfined sand and gravel deposits. There is little evidence of extensive lake-bed deposits (impermeable layers that can confine lower aquifers) in the upper part of the valley fill. Sand and gravel that was deposited as alluvial fans where tributaries enter the main valley forms a major part of the aquifer, and some of these tributaries provide large amounts of recharge to the aquifer through these fans. Several hydrologic processes affect the flow of water through the aquifer; the major ones (precipitation, evapotranspiration, surface-water runoff, and exchange between ground water and surface water) were investigated during this study and are discussed further on.

\section{Aquifer Framework}

The Meads Creek valley is long and relatively narrow; it is about $12 \mathrm{mi}$ long from north to south and averages $0.5 \mathrm{mi}$ wide (fig. 1). The valley-fill aquifer is primarily in the main part of the valley but extends up into some of the major tributary valleys, such as Dry Run in the southern part of the basin (fig. 1).

Of the 55 wells within the valley that were used in this study (fig. 3), 38 had records that included location, well depth, and depth to water, and 41 had stratigraphic information or designated type of aquifer (table 1). Most of those records were not sufficiently detailed, or the well was not deep enough, for construction of geologic sections that depict the entire thickness of the valley-fill deposits. Of the 55 wells with records, 45 had depth-to-water information. Ground-water levels were measured in 34 wells for this study.

Two seismic-refraction surveys were conducted to measure the thickness of the deposits near the northern and southern ends of Meads Creek valley (fig. 1). The greatest depth to bedrock along the seismic line in the northern end of the valley was about $125 \mathrm{ft}$ (fig. 6A), and about $150 \mathrm{ft}$ along the seismic line at the southern end (fig. 6B).

Most well records indicate that the upper part of the valley fill is unconfined. Unconfined aquifers are open to atmospheric pressure and to direct recharge from precipitation. The water level in one well, however, was slightly above land surface on the date of measurement (well SY 1093, fig. 3 and table 1), $1.7 \mathrm{ft}$ above the valley floor on June 1, 2007—an indication that this well may be finished in a part of the aquifer that is locally confined, or that the well is finished in bedrock, rather than in sand and gravel as reported.

\section{Sources of Recharge}

The valley-fill aquifer is recharged from three main sources: (1) precipitation that falls directly onto the aquifer surface; (2) upland sources that include (a) streams that lose water to the aquifer where they flow over alluvial fans in the main valley, and (b) runoff that enters the aquifer along its edges from adjacent till and bedrock hillsides; and (3) groundwater inflow from till and bedrock along the sides and bottom of the aquifer. A diagram of recharge sources and discharge locations for a typical valley-fill aquifer in central and western New York is shown in figure 7.

\section{Recharge from Precipitation on the Aquifer}

The average annual recharge from direct precipitation over the aquifer is about $14 \mathrm{in} / \mathrm{yr}$, as calculated from an average precipitation rate of $33 \mathrm{in} / \mathrm{yr}$ minus an estimated evapotranspiration rate of $19 \mathrm{in} / \mathrm{yr}$ (Kontis and others, 2004, pl. 1; and Randall, 1996). Recharge from precipitation that is not lost through evapotranspiration, or that does not flow overland, is assumed to seep through the soil and into the 


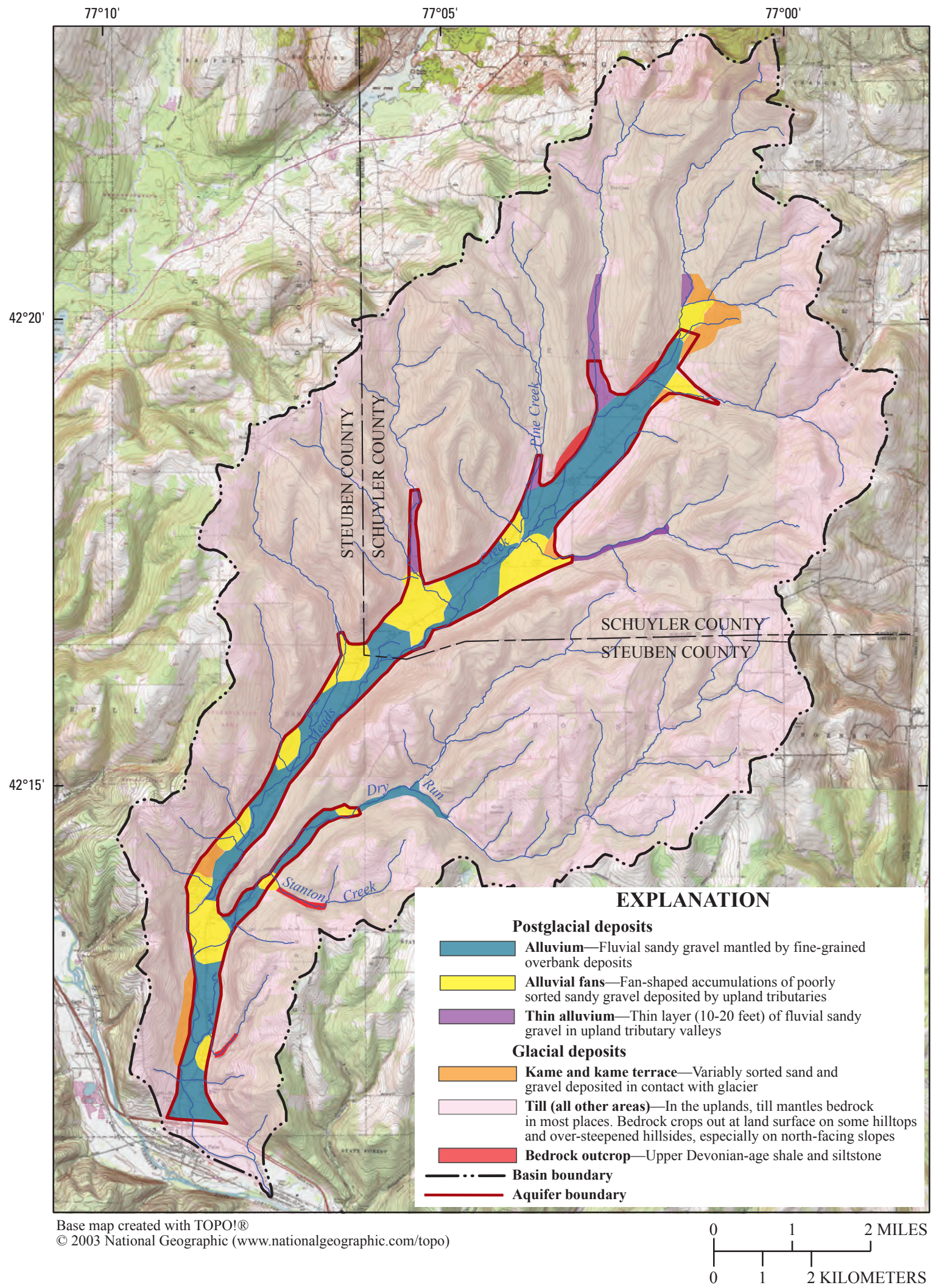

Figure 5. Surficial geology of the Meads Creek basin, Schuyler and Steuben Counties, N.Y. 
A

Northwest

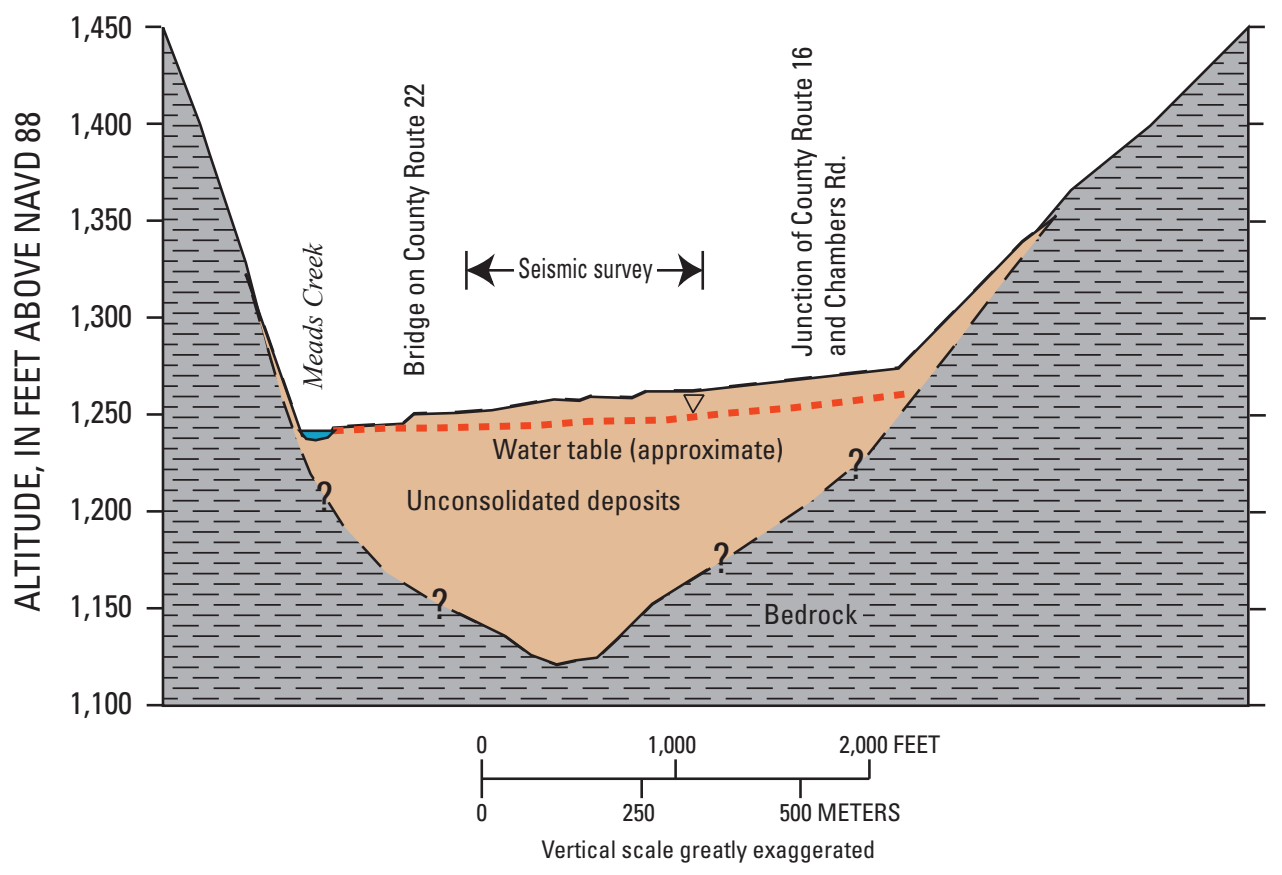

$A^{\prime}$

Southeast

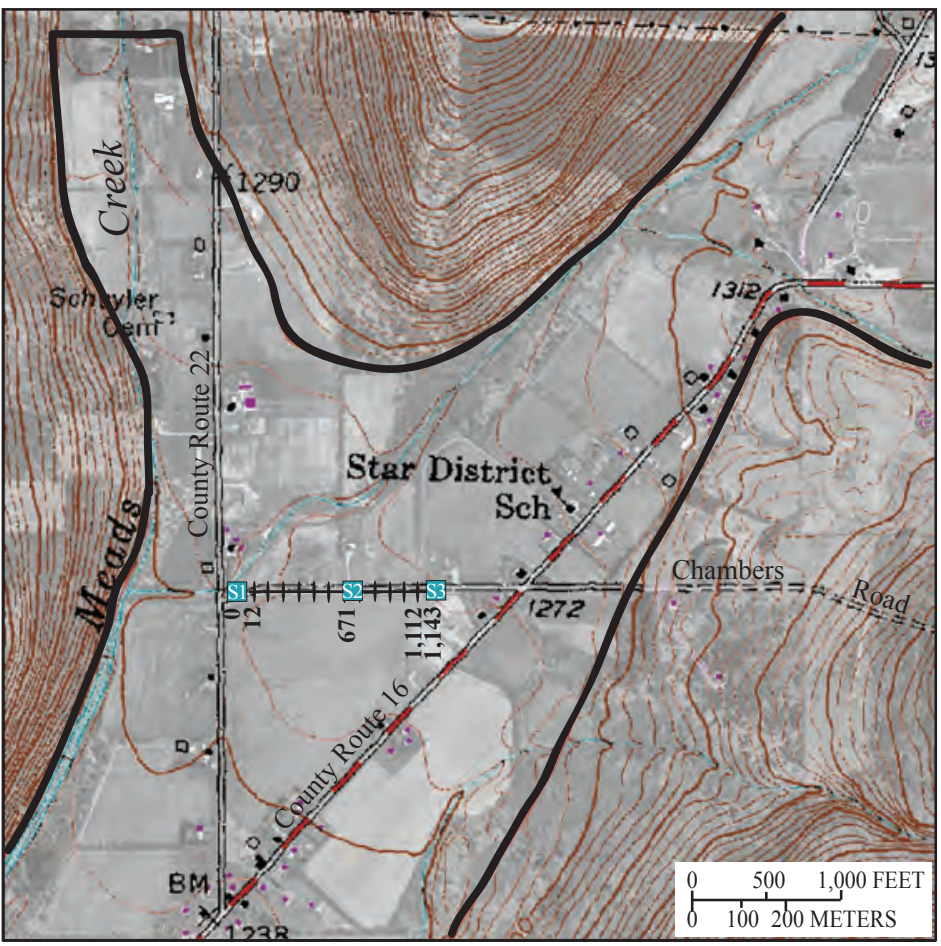

\section{EXPLANATION}

Seismic-refraction-survey line

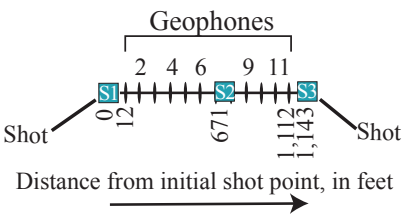

Aquifer boundary

Base from Schuyler County 12- and 24-inch resolution

Color Infrared Orthoimagery, New York State Office of Cyber

Security \& Critical Infrastructure Coordination, 2002

Figure 6. (A) Vertical section $A-A^{\prime}$ across Chambers Road near northern end of Meads Creek valley in the town of Orange, Schuyler County, N.Y., and map showing details of seismic-survey line. 

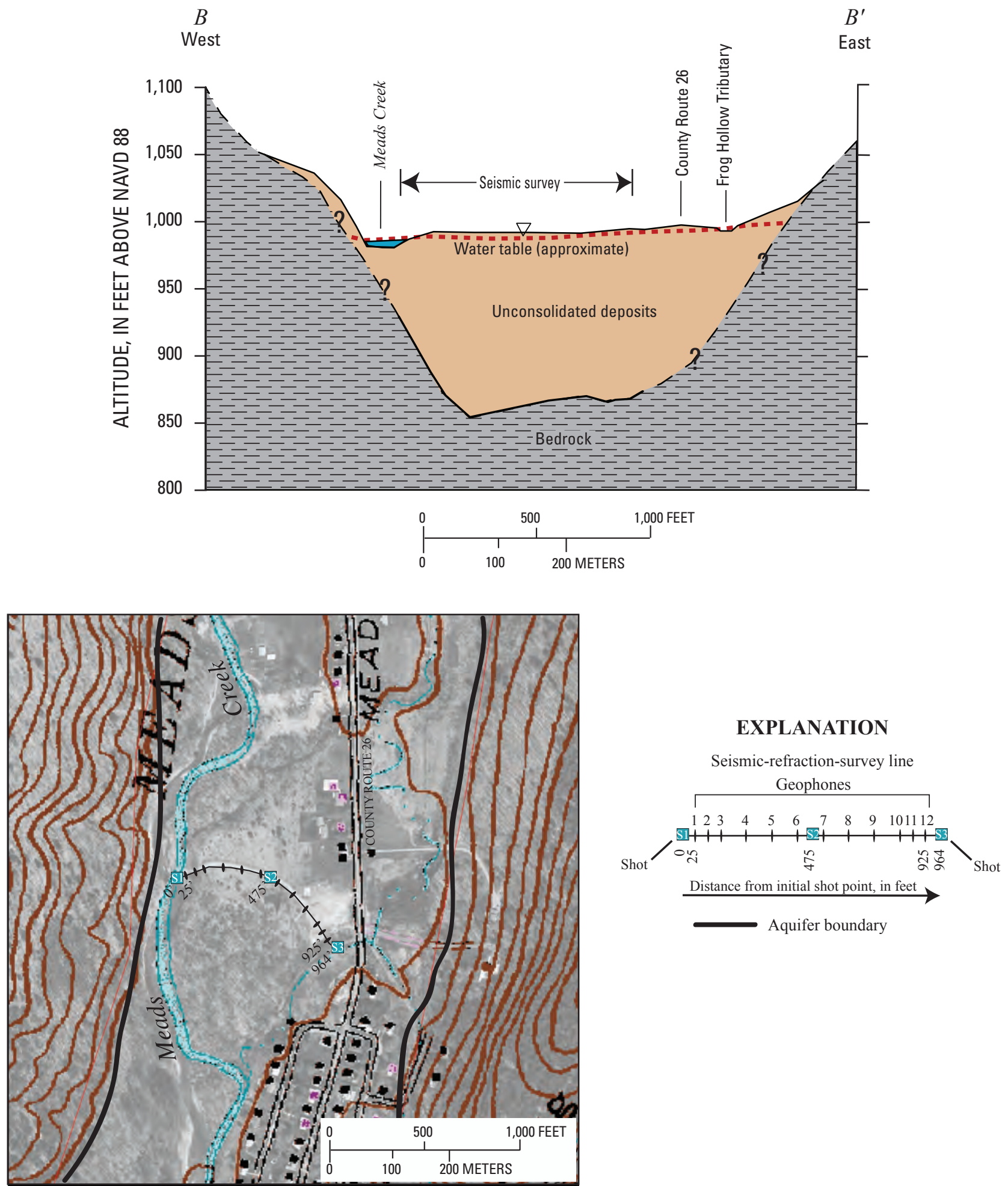

Base from Steuben County 12- and 24-inch resolution

Color Infrared Orthoimagery, New York State Office of Cyber

Security \& Critical Infrastructure Coordination, 2002

Figure 6. (B) Vertical section B-B' in the town of Campbell, near southern end of Meads Creek valley in Steuben County, N.Y., and map showing details of seismic-survey line. 


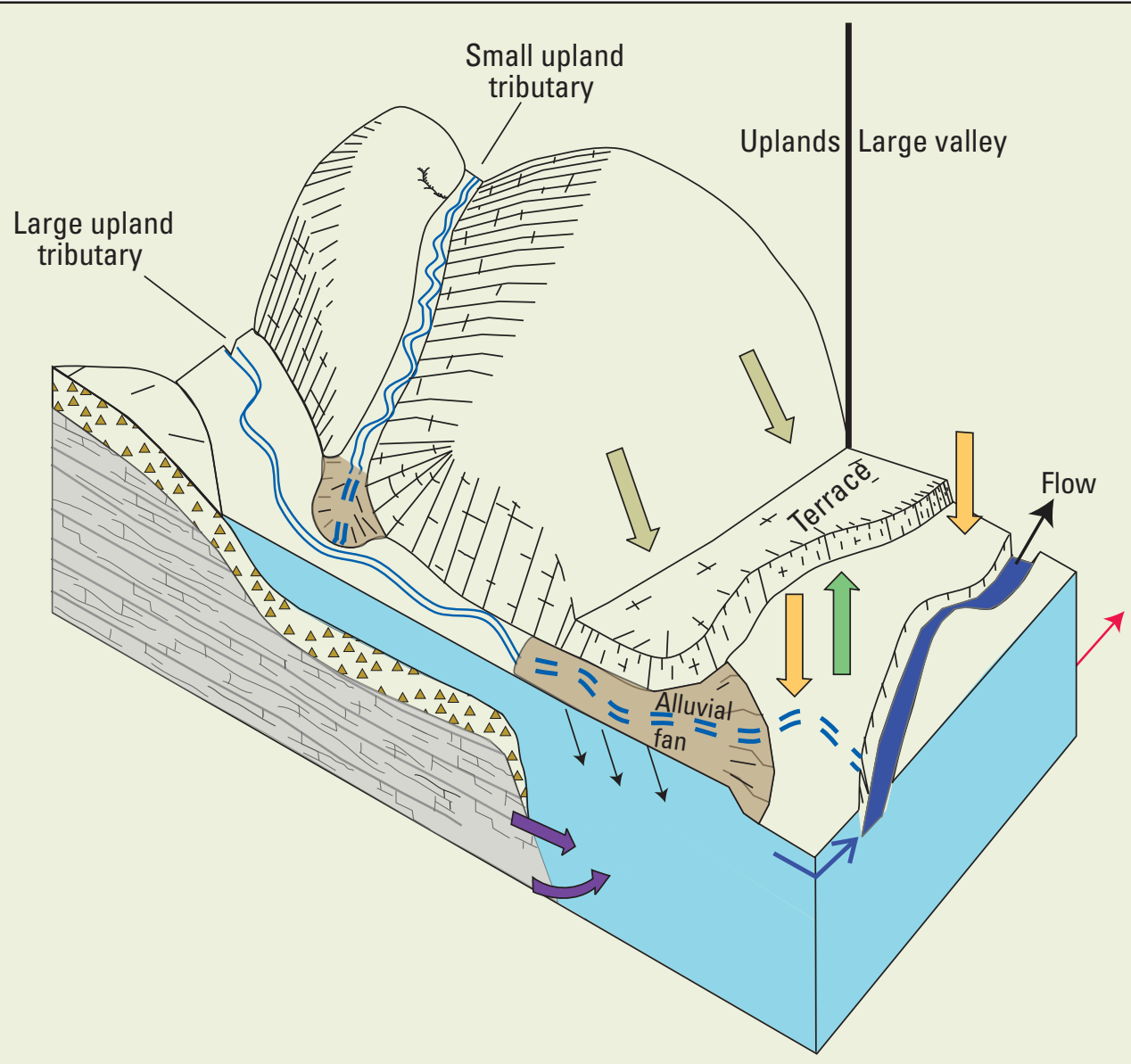

EXPLANATION

Unconsolidated valley-fill aquifer

$\Delta \Delta_{\Delta}^{\Delta}$ Till

$\mathrm{Q}$ Bedrock

Reach of tributary that gains water from ground-water discharge

$4>$ Reach of tributary that loses water to aquifer

Sources of recharge to valley-fill aquifers in large valleys

$\square$ Precipitation that falls directly over the valley floor and infiltrates to the water table unless diverted as evapotranspiration or as storm runoff from pavement or saturated soil

$\longrightarrow$ Unchanneled runoff and ground-water inflow from adjacent till-covered hillsides

$\square$ Lateral and upward flow from regional ground-water system through bedrock and till

$\longrightarrow$ Seepage losses from tributaries, typically where they flow over alluvial fans in major valleys

Sources of discharge from valley-fill aquifers in large valleys

$\rightleftarrows$ Evapotranspiration

1 Flow to main stream in valley

$\longrightarrow$ Ground-water outflow from aquifer into larger valley's aquifer deposits

Figure 7. Sources of recharge to, and discharge from, valley-fill aquifers in the glaciated Northeast. 
aquifer. The recharge rate of $14 \mathrm{in} / \mathrm{yr}$ over the surface area of the aquifer (about $6.2 \mathrm{mi}^{2}$ ) is equivalent to $6.4 \mathrm{ft}^{3} / \mathrm{s}$ or about $4.1 \mathrm{Mgal} / \mathrm{d}$ of recharge to the aquifer (table 2 ). This recharge value of $4.1 \mathrm{Mgal} / \mathrm{d}$ is within the range of yields computed for valley-fill aquifers in the eastern Oswego River basin, east of the study area (Kantrowitz, 1970).

\section{Recharge from Upland Sources}

The second source of recharge to the valley-fill aquifer is upland tributaries that lose water where they flow across their alluvial fans within the main valley before entering Meads Creek. Losing reaches were found to be more common in the southern part of the valley than in the northern part. A set of discharge measurements was made on seven tributaries and at three sites on Meads Creek on April 27, 2006 (table 3 and fig. 8), during a period of near-average, annual streamflow conditions, to estimate the amount of recharge the aquifer receives from losing streams and, thus, the amount of water that Meads Creek receives from ground water discharging into its main channel. The discharge measurements in the tributaries were made in pairs, whereby the upstream measurement was made near the boundary between the valleyfill aquifer and the uplands, and the downstream measurement was made near the mouth of each tributary just above the point at which it joins the main channel of Meads Creek (fig. 8).

Seepage to or from a stream reach was calculated as the difference between the measured upstream discharge and the measured downstream discharge along that reach during base-flow conditions. In some tributaries where flow could not be measured, discharges were estimated based on the results from the nine measured tributaries (table 3). A downstream gain of discharge indicates an increase in flow to the stream channel from ground water discharging into that channel, whereas a downstream decrease in discharge indicates that the stream loses water to the aquifer through its bed. The discharge measurements of April 27, 2006, were made over an 8-hour period of base-flow conditions, a period when most streamflow was from ground water discharging into the channel. No precipitation had been recorded within the basin during the preceding week. A slight recession during the previous week at the nearest streamflow gage (Cohocton River near Campbell, NY, 01529500, fig. 1) also confirmed that this was a period of base flow. The results of the measurements indicate that:

1. Meads Creek gained about $61 \mathrm{ft}^{3} / \mathrm{s}$ (as ground-water seepage and tributary inflows) in the 10.2-mi reach from measurement sites 3 to 18 , or about $6 \mathrm{ft}^{3} / \mathrm{s}$ ) $/ \mathrm{mi}$ of stream length (fig. 8 and table 3).

2. Streamflow gain in Meads Creek from ground water (excluding tributary inflow) was $11.3 \mathrm{ft}^{3} / \mathrm{s}$ in the northern part of the valley (sites 3 to 9 , fig. 8 ) and $17.2 \mathrm{ft}^{3} / \mathrm{s}$ in the southern part (sites 9 to 18 , fig. 8) - a total of $28.5 \mathrm{ft}^{3} / \mathrm{s}$ (fig. 8 and table 3).
3. Tributaries in the northern part of the basin typically gained water-an indication that they were not significant sources of recharge to the aquifer during that period. An exception was Coons Hollow Creek (sites 6A and 6B, fig. 8), which was observed to lose water mostly along the lower part of its alluvial fan (site 6B, fig. 8).

4. Tributaries in the central and southern part of the basin beginning south of Coons Hollow Creek typically lost water and were significant sources of recharge to the aquifer (fig. 8 and table 3). Streamflow losses to the valley-fill aquifer from tributaries in the southern part of the basin (sites 13A and 13B, 14A and 14B, 15A and $15 \mathrm{~B}$, and $16 \mathrm{~A}$ and 16B; table 3 and fig. 8) were calculated from the discharge measurements to total about $2.5 \mathrm{ft}^{3} / \mathrm{s}$ (table 3 and fig. 8). Seepage losses from unmeasured tributaries were estimated to total $4.5 \mathrm{ft}^{3} / \mathrm{s}$, which when added to the losses in measured tributaries $\left(2.5 \mathrm{ft}^{3} / \mathrm{s}\right)$ results in a total streamflow loss as recharge to the valleyfill aquifer of $7.0 \mathrm{ft}^{3} / \mathrm{s}$ or $4.5 \mathrm{Mgal} / \mathrm{d}$ (table 2).

Water from the other source of upland recharge to the aquifer - overland runoff and ground-water inflow from unchanneled hillsides that slope toward the aquifer-enters the valley-fill aquifer at the base of the hillsides. The rate of recharge from this source was estimated as the total area of valley wall, $8.4 \mathrm{mi}^{2}$ or $2.34 \times 10^{8} \mathrm{ft}^{2}$ ) (fig. 9) (excluding where the stream channel on the valley floor is adjacent to the hillside and intercepts the runoff before it enters the aquifer), multiplied by $1.17 \mathrm{ft} / \mathrm{yr}$, the average annual rate of ground-water recharge to the aquifer from precipitation minus evapotranspiration (discussed in the Recharge from Precipitation on the Aquifer section) (table 2); this yielded a total recharge rate of $2.74 \times 10^{8} \mathrm{ft}^{3} / \mathrm{yr}$ or $8.7 \mathrm{ft}^{3} / \mathrm{s}(5.7 \mathrm{Mgal} / \mathrm{d})$. Recharge from unchanneled hillsides represents about 38 percent of the total recharge to the valley-fill aquifer (table 2), a value that is within the range of 16- to 50-percent determined for valley-fill aquifers in the glaciated Northeast (Kontis and others, 2004, table 5).

\section{Recharge from Deep Ground-Water Inflow}

A minor component of recharge to the unconsolidated valley-fill aquifer is ground water from the deeper portions of the flow system that discharges into the sides and bottom of the aquifer from the surrounding till and bedrock (table 2). This component of a ground-water budget in valley-fill aquifers in the glaciated Northeast has not been investigated in detail and is usually a component of the budget that is estimated after the other major components have been derived. A.D. Randall (U. S. Geological Survey, written commun., 2008) suggests that this deep component of the ground-water budget is small or negligible in most cases because shale is relatively impermeable, especially at depth. The portion of the water budget that was unaccounted for and represents deep ground-water recharge from the deep flow system originating in the surrounding shale and till uplands was estimated to be 
Table 2. Water budget for Meads Creek valley-fill aquifer in Schuyler and Steuben Counties, N.Y., based on water-budget components and measured ground-water discharge to main channel of creek, April 27, 2006.

$\left[\mathrm{ft}^{2}\right.$, feet squared; $\mathrm{ft}^{3} / \mathrm{s}$, cubic feet per second; $\mathrm{ft} / \mathrm{d}$, feet per day; $\mathrm{ft}^{3} / \mathrm{d}$, cubic feet per day; Mgal/d, million gallons per day; Est., estimated; $\mathrm{ft} / \mathrm{ft}$, foot per foot; $K$, hydraulic conductivity; in/y, inch per year]

\begin{tabular}{|c|c|c|c|c|}
\hline Budget component & $\mathrm{ft}^{3} / \mathrm{s}$ & $\mathrm{ft}^{3} / \mathbf{d}$ & Mgal/d & $\begin{array}{c}\text { Percentage } \\
\text { of total }\end{array}$ \\
\hline \multicolumn{5}{|l|}{ A. Recharge to valley-fill aquifer } \\
\hline \multicolumn{5}{|l|}{ Upland sources } \\
\hline Streamflow loss from tributaries (measured and Est.) & 7.0 & $6.1 \times 10^{5}$ & 4.5 & 32 \\
\hline Ground-water inflow from till and bedrock beneath and on sides of aquifer (Est.) & 0.5 & $4.3 \times 10^{4}$ & 0.3 & 2 \\
\hline Total average recharge to aquifer & 22.6 & $2.0 \times 10^{6}$ & 14.6 & 100 \\
\hline \multicolumn{5}{|l|}{ B. Discharge from unconsolidated valley-fill aquifer } \\
\hline Ground-water discharge to Meads Creek on April 27, $2006^{2}$ & 21.4 & $1.9 \times 10^{6}$ & 13.8 & 94 \\
\hline \multicolumn{5}{|c|}{$\begin{array}{l}{ }^{2} \text { Ground-water discharge is adjusted by } 0.67 \text { except for the portion of discharge that is derived from losing tributaries }\left(7.0 \mathrm{ft}^{3} / \mathrm{s}\right) \text { because the rate of loss in } \\
\text { the tributaries is uniform under base-flow conditions. The } 0.67 \text { adjustment is based on comparison of mean annual base flow at Cohocton River at Campbell } \\
\left(258 \mathrm{ft}^{3} / \mathrm{s}\right) \text {. Discharge of the Cohocton River on April 27, 2006, was } 388 \mathrm{ft}^{3} / \mathrm{s} \text {, about } 33 \text { percent greater than at mean base flow; therefore, the measured ground- } \\
\text { water discharge in Meads Creek on that date was assumed to be } 33 \text { percent greater (adjustment of } 0.67 \text { ) than for long-term, average conditions. }\end{array}$} \\
\hline
\end{tabular}

$0.5 \mathrm{ft}^{3} / \mathrm{s}(0.3 \mathrm{Mgal} / \mathrm{d})$. This amount was only 2 percent of the total recharge to the valley-fill aquifer system.

\section{Ground-Water Discharge and Direction of Movement}

Most of the water in the valley-fill aquifer discharges into the main channel of Meads Creek, as described previously, and about 6 percent leaves the valley as underflow where the Meads Creek valley enters the Cohocton River valley (table 2). The amount of ground water discharged from pumping wells in the valley is thought to be less than 1 percent because all private households have septic systems and all ground water withdrawn is effectively returned to the ground through the septic systems. The only net ground-water loss from pumping is from two trailer parks at the southern end of the valley where about 400 people reside and household water is treated and discharged to Meads Creek through local waste-water treatment facilities - and based on an average withdrawal rate of $100 \mathrm{gal} / \mathrm{d}$ per person is estimated as 0.3 percent of the total calculated ground-water discharge from the valley-fill aquifer, which is considered negligible in the overall water budget. Ground-water discharge to the main channel of Meads Creek and to the gaining reaches of tributaries was estimated from streamflow measurements. Discharge out of the valley was estimated as deep underflow at the southern end of the valley and was calculated from Darcy's equation for discharge through a porous medium, as discussed in the Water Budget section further on.

\section{Gaining Streams}

Most of the discharge from valley-fill aquifers in much of western and central New York typically occurs along the main stem of the valley stream (Kontis and others, 2004). The ground-water component of flow (discharge from the aquifer) in Meads Creek in the 10.2-mi reach between measurement sites 3 and 18 (fig. 9) on April 27, 2006, was $28.5 \mathrm{ft}^{3} / \mathrm{s}$ (table 3) - the sum of the ground-water contribution in the central part of the aquifer (sites 3 to $9,11.3 \mathrm{ft}^{3} / \mathrm{s}$ ) and that in the southern part (from sites 9 to $18,17.2 \mathrm{ft}^{3} / \mathrm{s}$ ) (table 3 ). The streamflow gain that is attributed to ground-water discharge per stream mile in the northern reach was $2.4\left(\mathrm{ft}^{3} / \mathrm{s}\right) / \mathrm{mi}$, and that in the southern reach was $3.2\left(\mathrm{ft}^{3} / \mathrm{s}\right) / \mathrm{mi}$; thus, streamflow gain over the entire measured reach of Meads Creek (sites 3 to 18 ) averaged $2.8\left(\mathrm{ft}^{\mathrm{t}} / \mathrm{s}\right) / \mathrm{mi}$ (table 3$)$.

Although the streamflow measurements of April 27, 2006, were made during a period that had been considered to represent average annual ground-water levels, streamflow 
Table 3. Measured and estimated gaining and losing reaches along Meads Creek and selected tributaries on April 27, 2006, in Meads Creek valley, Schuyler and Stuben counties, N.Y.

[USGS, U.S. Geological Survey; $\mathrm{mi}^{2}$, square miles, $\mathrm{ft}^{3} / \mathrm{s}$, cubic feet per second; ( $\left.\mathrm{ft}^{3} / \mathrm{s}\right) / \mathrm{mi}$, cubic feet per second per mile of stream length; mi, mile; Trib., tributary; Est., estimated; Cr, County Route]

\begin{tabular}{|c|c|c|}
\hline $\begin{array}{c}\text { Measurement } \\
\text { site } \\
\text { number } \\
\text { (location } \\
\text { shown } \\
\text { on fig. 8) }\end{array}$ & $\begin{array}{c}\text { USGS } \\
\text { site } \\
\text { number }\end{array}$ & Site name \\
\hline
\end{tabular}

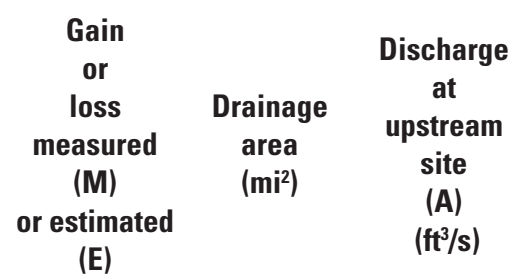

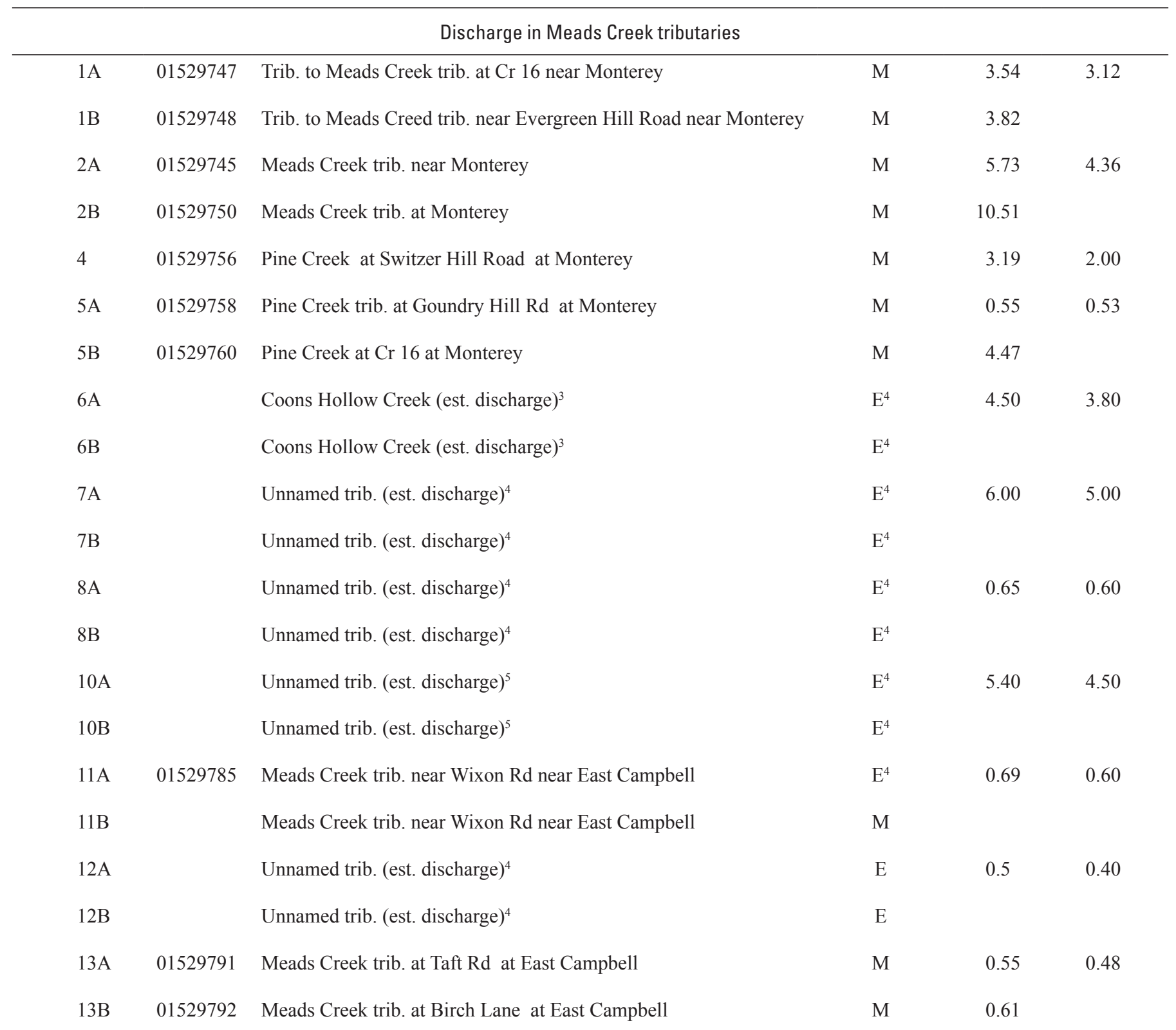


Table 3. Measured and estimated gaining and losing reaches along Meads Creek and selected tributaries on April 27, 2006 in Meads Creek valley, Schuyler and Stuben counties, N.Y.-Continued

$\left[\mathrm{mi}^{2}\right.$, square miles, $\mathrm{ft}^{3} / \mathrm{s}$, cubic feet per second; ( $\left.\mathrm{ft}^{3} / \mathrm{s}\right) / \mathrm{mi}$, cubic feet per second per mile of stream length. Trib., tributary; Est., estimated; Cr, County Route. Locations of measurement sites are shown in fig. 8.]

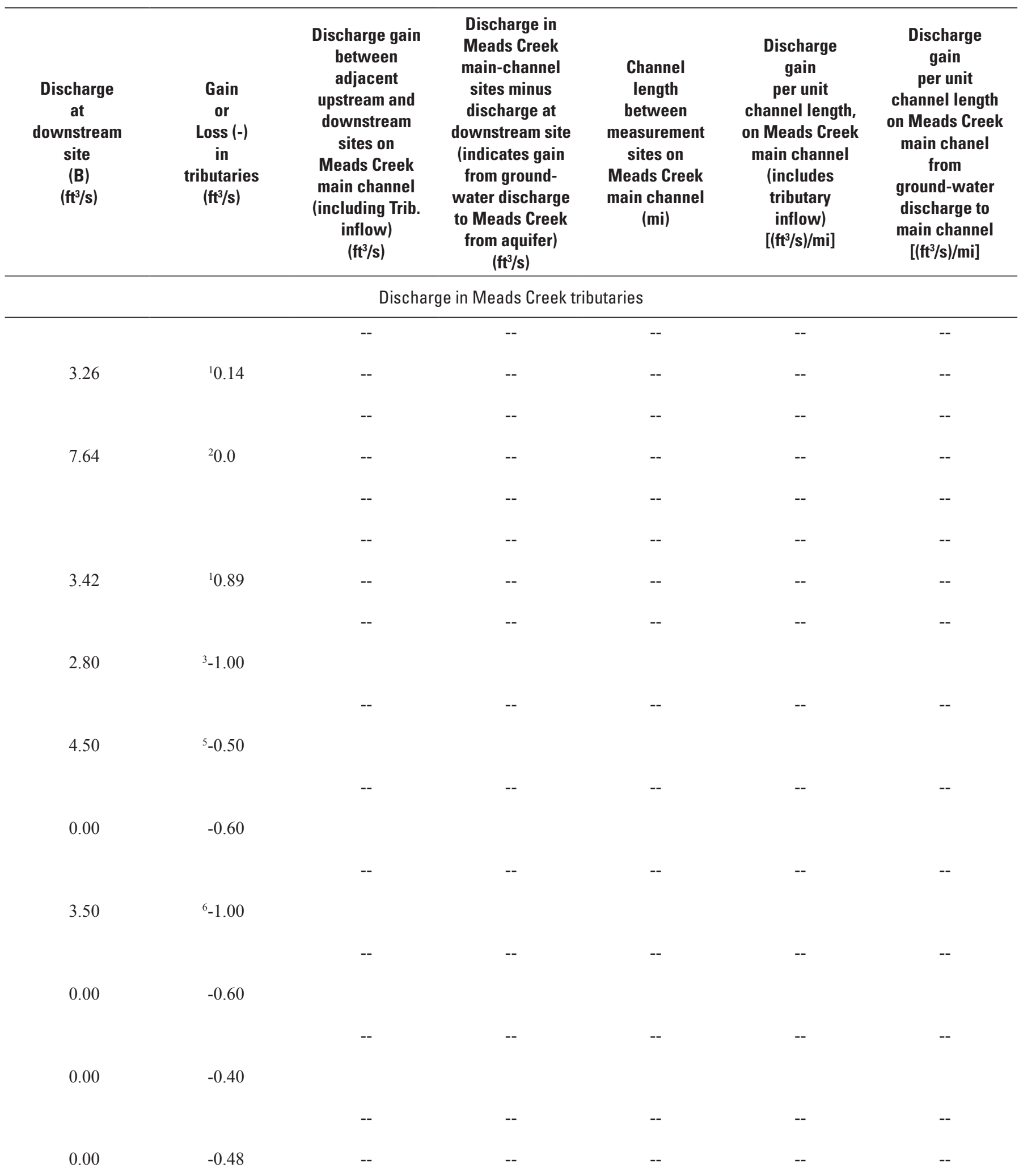


Table 3. Measured and estimated gaining and losing reaches along Meads Creek and selected tributaries on April 27, 2006, in Meads Creek valley, Schuyler and Stuben counties, N.Y.-Continued

[USGS, U.S. Geological Survey; $\mathrm{mi}^{2}$, square miles, $\mathrm{ft}^{3} / \mathrm{s}$, cubic feet per second; ( $\left.\mathrm{ft}^{3} / \mathrm{s}\right) / \mathrm{mi}$, cubic feet per second per mile of stream length; mi, mile; Trib., tributary; Est., estimated; Cr, County Route]

\begin{tabular}{cc} 
Measurement & \\
site & USGS \\
number & site \\
(location & number \\
shown & \\
on fig. 8) & \\
\hline
\end{tabular}

Site name

Site name

\begin{tabular}{|c|c|c|}
\hline $\begin{array}{c}\text { Gain } \\
\text { or } \\
\text { loss } \\
\text { measured } \\
\text { (M) } \\
\text { or estimated }\end{array}$ & $\begin{array}{c}\text { Drainage } \\
\text { area } \\
\left(\mathrm{mi}^{2}\right)\end{array}$ & $\begin{array}{c}\text { Discharge } \\
\text { at } \\
\text { upstream } \\
\text { site } \\
\text { (A) } \\
\left.\text { (ft } \text { ft }^{3} / \mathbf{s}\right)\end{array}$ \\
\hline
\end{tabular}

\begin{tabular}{ccllcc}
\hline 14A & 01529793 & Stanton Creek at Gulf Road at East Campbell & M & 1.55 & 1.21 \\
14B & 01529794 & Stanton Creek at Dry Run Road at East Campbell & M & 1.59 \\
15A & 152979505 & Dry Run at Dry Run Road at East Campbell & M & 17.61 & 17.90 \\
15B & 152979510 & Dry Run at Meads Creek Road at East Campbell & M & 18.40 \\
16A & 01529797 & Meads Creek trib. near Frog Hollow Rd near Coopers Plains & M & 0.95 & 0.84 \\
16B & 152979705 & Meads Creek trib. at Cr 26 near Coopers Plains & M & 1.00 & 0.40 \\
17A & & Unnamed trib. (est. discharge) & E & 0.5 & \\
17B & & Unnamed trib. (est. discharge) & E & & \\
\hline
\end{tabular}

\begin{tabular}{clllll}
\hline \multicolumn{3}{c}{ Discharge in Meads Creek main channel } & & & \\
\hline 3 & 01529752 & Meads Creek at Monterey & M & 16.0 & 10.8 \\
9 & 01529780 & Meads Creek at Meads Creek & M & 40.8 & 32.8 \\
18 & 01529798 & Meads Creek near Coopers Plains & M & 68.4 & 71.4 \\
& & & & & \\
\end{tabular}

\footnotetext{
${ }^{1}$ Percent gain or loss within margin of error (10 percent of upstream discharge value).

${ }^{2}$ No net ground-water gain in this reach (Total difference in streamflow between sites $2 \mathrm{~A}$ and $2 \mathrm{~B}$ due to inflow from tributary at site $1 \mathrm{~B}$ ).

${ }^{3}$ Streamflow loss of $1.0 \mathrm{ft}^{3} / \mathrm{s}$ estimated by visual inspection of flow.

${ }^{4}$ Discharge estimated for upstream site (A) by multiplying drainage area of unmeasured, unnamed tributaries by average discharge per square mi of measured tributaries $\left(0.84\left(\mathrm{ft}^{3} / \mathrm{s}\right) / \mathrm{mi}^{2}\right)$. All estimated discharges rounded to the nearest $0.1 \mathrm{ft}^{3} / \mathrm{s}$.

${ }^{5}$ Streamflow loss of $0.5 \mathrm{ft}^{3} / \mathrm{s}$ estimated as somewhat less than Coons Hollow site (6) due to shorter reach that flows over the aquifer.

${ }^{6}$ Streamflow loss of $1.0 \mathrm{ft}^{3} / \mathrm{s}$ estimated as similar to Coons Hollow site (6).

${ }^{7}$ Ground-water discharge is adjusted by multiplying by 0.67 except for the portion of discharge that is derived from losing tributaries ( $7.0 \mathrm{ft} / \mathrm{s}$ ) because the rate of loss in the tributaries is uniform under base-flow conditions. Estimate is based on comparison of mean annual base flow at Cohocton River at Campbell $\left(258 \mathrm{ft}^{3} / \mathrm{s}\right)$. Discharge of Cohocton River on April 27, 2006, was $388 \mathrm{ft}^{3} / \mathrm{s}$, about 33 percent greater than at mean base flow; therefore, the measured groundwater discharge in Meads Creek on that date was assumed to be 33 percent greater (multiplication by 0.67 ) than for long-term, average conditions. $[((28.5-7) * 0.67)+7=21.4]$.
} 
Table 3. Measured and estimated gaining and losing reaches along Meads Creek and selected tributaries on April 27, 2006 in Meads Creek valley, Schuyler and Stuben counties, N.Y.-Continued

$\left[\mathrm{mi}^{2}\right.$, square miles, $\mathrm{ft}^{3} / \mathrm{s}$, cubic feet per second; $\left(\mathrm{ft}^{3} / \mathrm{s}\right) / \mathrm{mi}$, cubic feet per second per mile of stream length. Trib., tributary; Est., estimated; Cr, County Route. Locations of measurement sites are shown in fig. 8.]

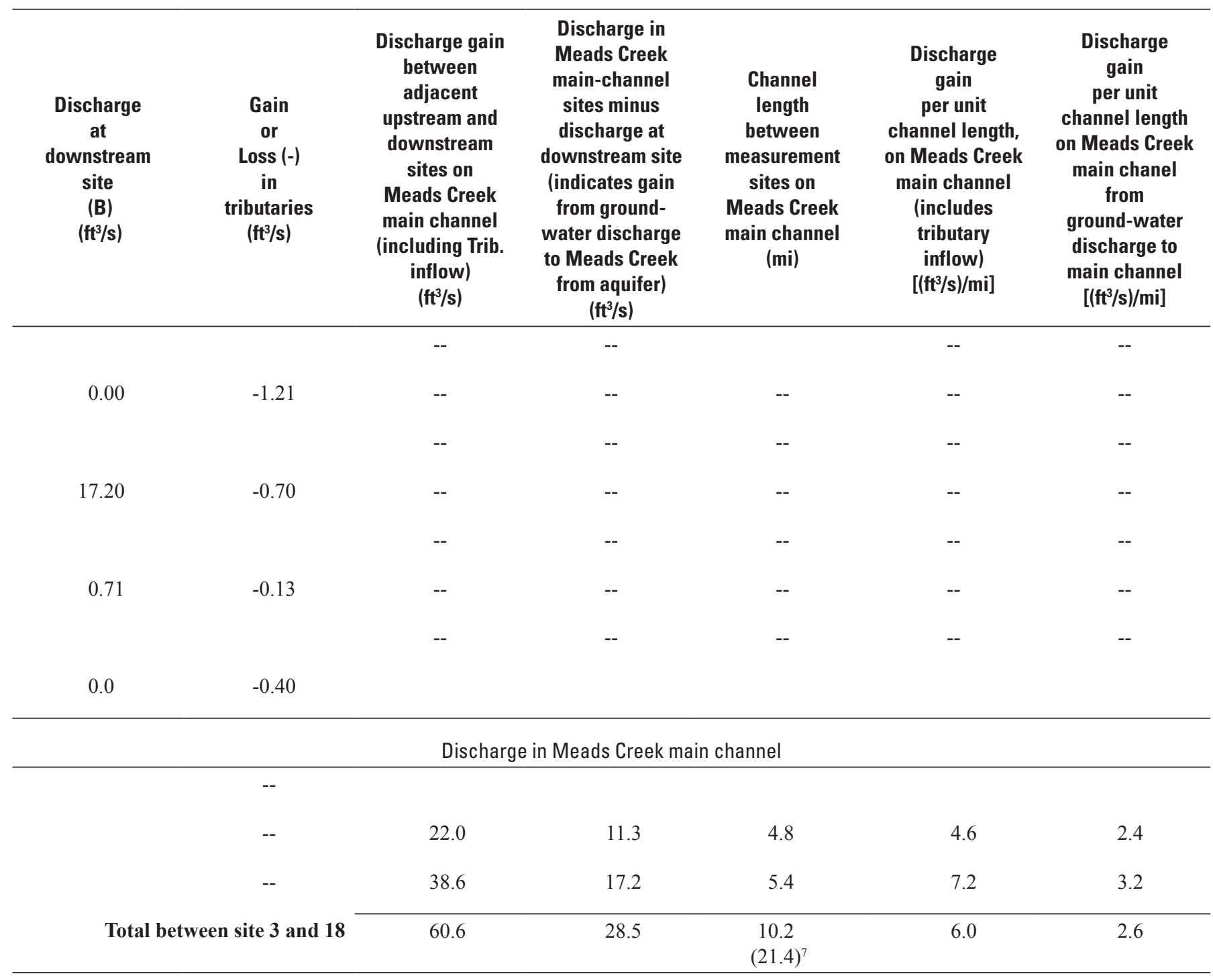




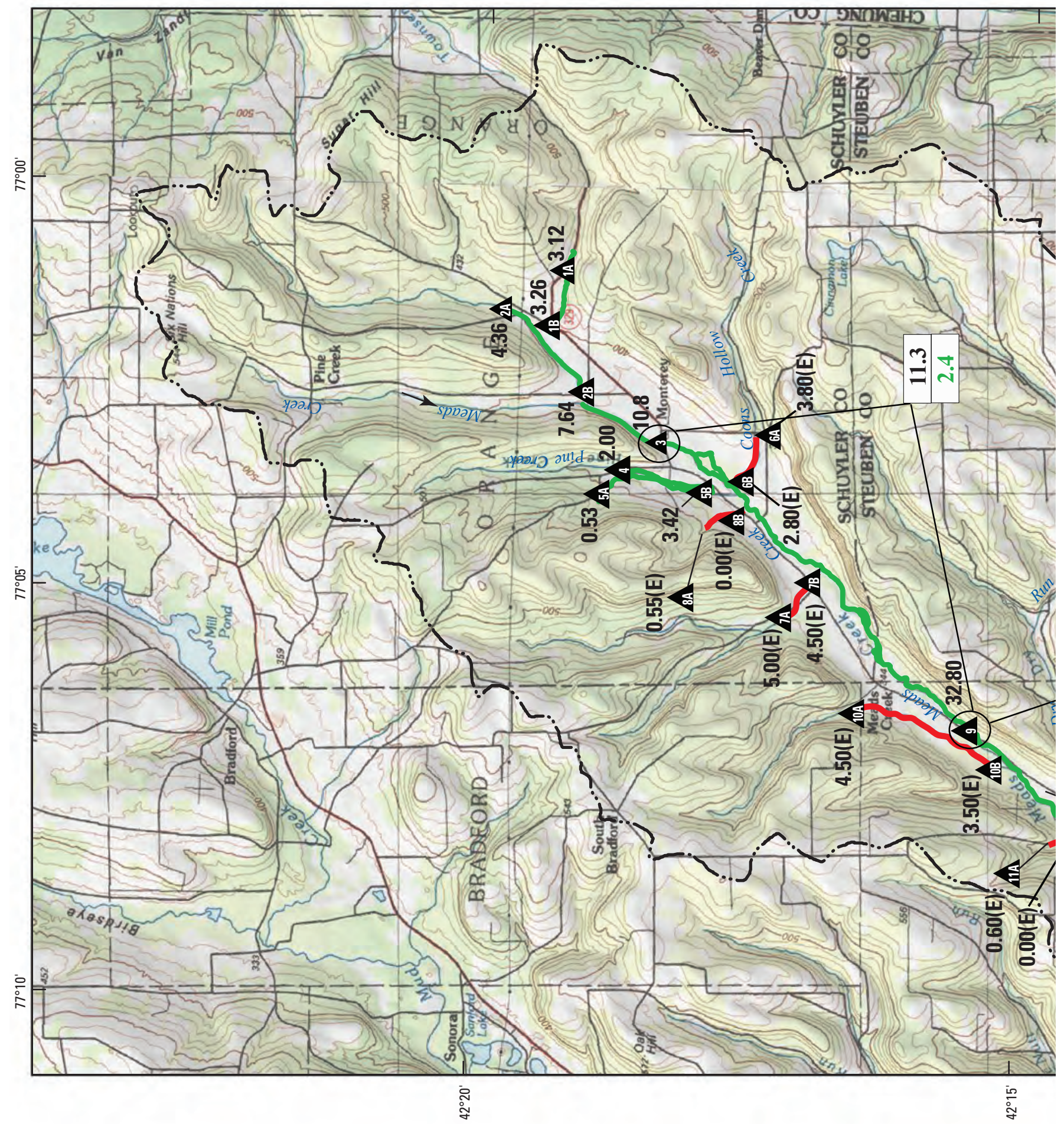



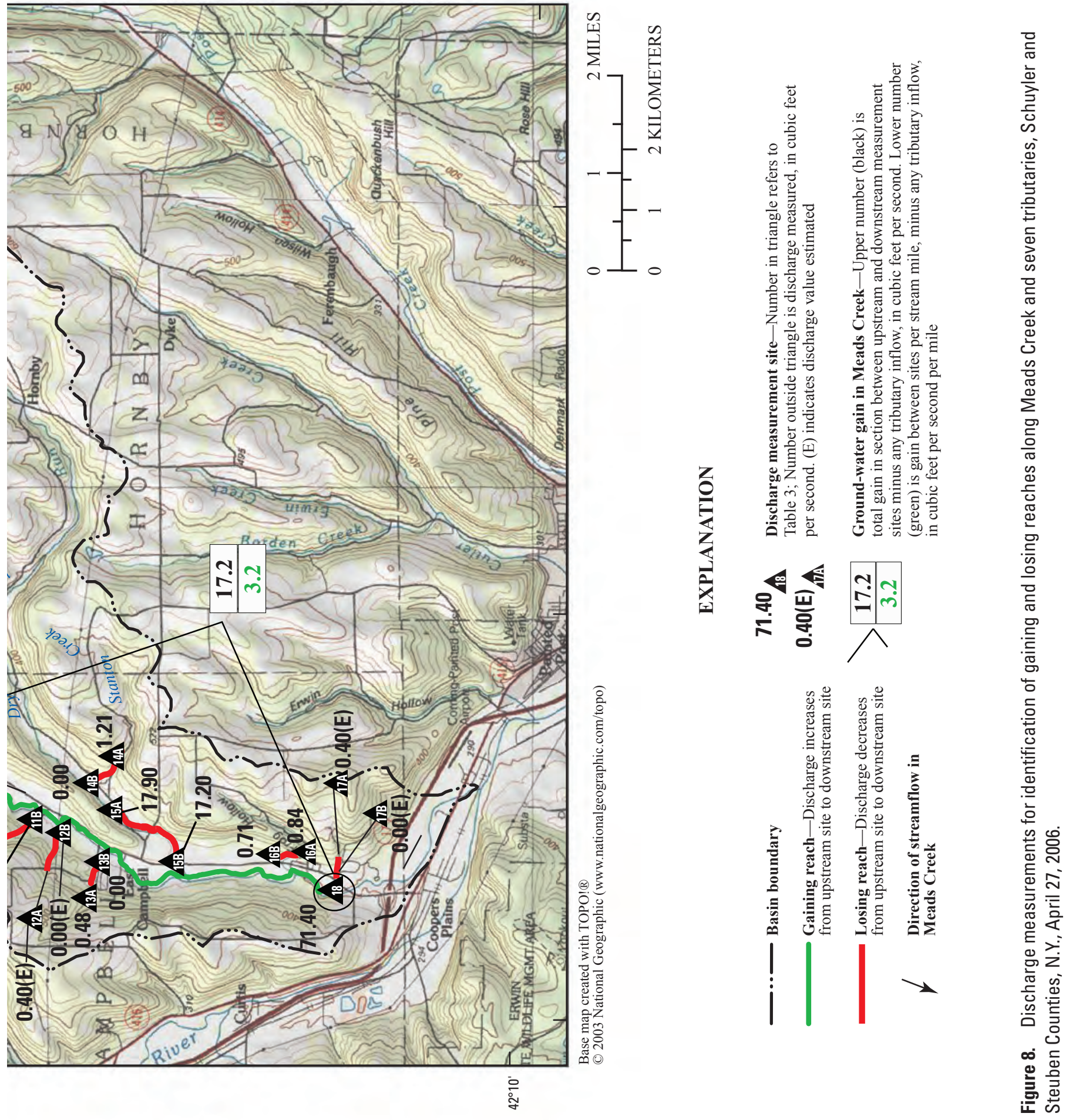


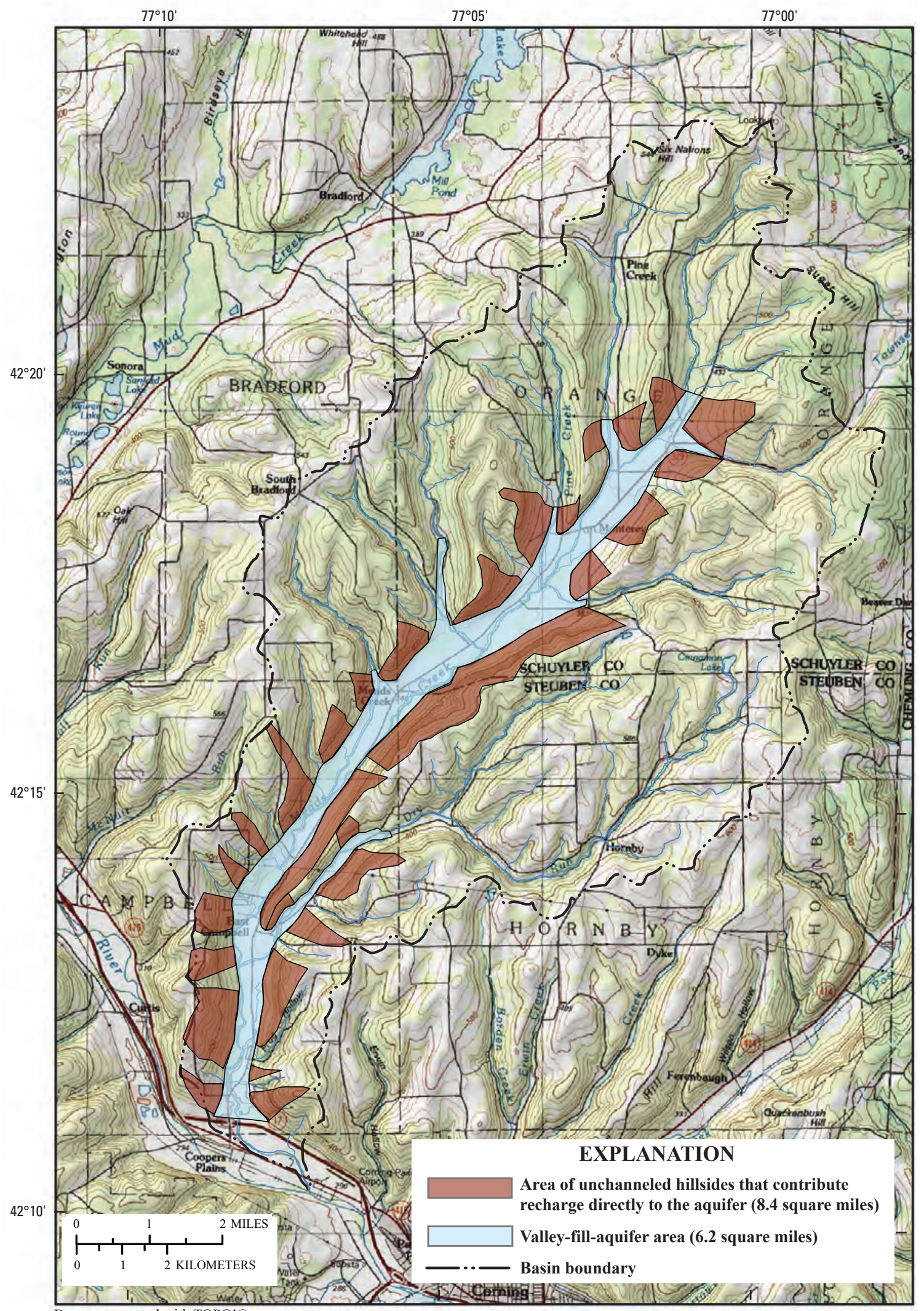

Base map created with TOPO!

(C) 2003 National Geographic (www.nationalgeographic.com/topo)

Figure 9. Areas of unchanneled hillsides adjacent to the valley-fill aquifer that contribute recharge directly to the aquifer in the Meads Creek valley, Schuyler and Steuben Counties, N.Y. 
on that date was about 33 percent above its annual base-flow average, as inferred from flow conditions on that day at the nearest continuous-record streamflow gage (Cohocton River at Campbell) (fig. 1). Accordingly, the streamflow measurements and the estimated ground-water discharge into Meads Creek that day were assumed to also be about 33 percent greater than during a period of long-term, average annual base flow, and the average annual rate of ground-water discharge into Meads Creek (28.5 ft $3 / \mathrm{s}$, table 3 ) was therefore adjusted downward by 33 percent (multiplied by 0.67 ) to obtain a final value of $21.4 \mathrm{ft}^{3} / \mathrm{d}$ or $13.8 \mathrm{Mgal} / \mathrm{d}$ (table 2).

\section{Ground-Water Underflow}

The third component of ground-water discharge from the Meads Creek valley-fill aquifer is deep ground-water outflow through the southern end of the valley, where the aquifer joins the unconsolidated deposits in the Cohocton River valley. This value was computed from (1) an estimated hydraulic conductivity of $180 \mathrm{ft} / \mathrm{d}$, which is a reasonable value for alluvial sand and gravel deposits with some fines interspersed in central and western New York (Kontis and others, 2004, fig. 12 ), (2) a potentiometric-surface gradient of about $0.003 \mathrm{ft} / \mathrm{ft}$ near the southern seismic-refraction-survey area derived from a potentiometric-surface map of the valley-fill aquifer (fig. 10), and (3) a 190,000- $\mathrm{ft}^{2}$ cross-sectional area of the valley-fill aquifer as indicated from the seismic-refractionsurvey data at the southern end of the valley (fig. 6B). These values were applied to the simplified Darcy's equation for flow through a uniformly porous medium (Darcy, 1856):

$$
Q=K i A
$$

Where;

$$
\begin{aligned}
Q= & \text { discharge through the cross-sectional area } \\
& \text { of the aquifer, in cubic feet per second, } \\
K \quad & \text { hydraulic conductivity of the aquifer, in feet } \\
& \text { per day, } \\
i \quad & \text { hydraulic gradient of the potentiometric } \\
& \text { surface of the aquifer, and } \\
=\quad & \text { cross-sectional area of the aquifer, in } \\
& \text { square feet }
\end{aligned}
$$

This calculation yields a value of $1.2 \mathrm{ft}^{3} / \mathrm{s}(0.8 \mathrm{Mgal} / \mathrm{d})$ for underflow exiting the mouth of the valley.

\section{Ground-Water Levels and Ground- Water Movement}

Ground-water levels in 29 wells finished in the valley-fill deposits were measured on June 1, 2, and 5, 2007 (table 1), to plot the depth to the water table and the directions of groundwater flow in the valley-fill aquifer. Well depths ranged from 16 to $73 \mathrm{ft}$; the median depth was $35 \mathrm{ft}$, and the mean depth was $37 \mathrm{ft}$ (table 1). Ground-water levels ranged from $1.77 \mathrm{ft}$ above land surface at well SB 1093 to $23.57 \mathrm{ft}$ below land surface at well SB 478 (fig. 3). The median depth to water in all measured wells was $9.27 \mathrm{ft}$, and the mean depth was $10.26 \mathrm{ft}$ below land surface (table 1). One well (SY 1093) was under artesian flowing conditions, but the well log showed no evidence of a confining layer, although a ground-water level that is above land surface suggests either the presence of a thin confining unit that was not detected during drilling, or an inaccuracy in the well record - the well possibly is finished in a confined zone in the bedrock. Other than this anomaly, no other information from drillers' logs or waterlevel measurements indicated the presence of a confined aquifer in the upper part of the valley fill; however, detailed well logs and additional drilling would be needed to verify this assumption.

The water-level measurements were made during a period of slightly below-average annual water-table conditions and slightly above average annual base-flow conditions, as explained in the Methods section. A period of averageannual conditions was desirable because the data would be appropriate for calibration of a future steady-state groundwater-flow model that would represent average, steady-state annual ground-water levels within the Meads Creek valley-fill aquifer. The measured ground-water levels were converted to altitudes above NAVD 88 and plotted on a topographic map, and then were contoured as a potentiometric-surface map of the aquifer (fig. 10).

In addition to the ground-water-level measurements, ground-water altitudes that were also used to guide the placement of potentiometric-surface contours were derived from topographic maps at locations where topographic contours intersected the channels of stream reaches that were gaining flow. Gaining reaches on the main channel and tributaries represent locations where ground-water altitudes are at, or near, land surface because the stream channels are hydraulically connected to the aquifer at these locations and this information can be used to guide the position of the potentiometric-surface contours.

Ground-water levels generally were deepest on the upper parts of alluvial fans (wells SB 485 and SY 4) and shallowest in the flood plain, especially in wells close to Meads Creek (wells SB 1829 and SB 100). One reason for recurrent flooding in the Meads Creek valley, especially near the main channel, may be that the relatively high water table (median measured depth $9.27 \mathrm{ft}$ below land surface) results in a thin unsaturated zone that leaves relatively little capacity for storage of additional infiltration; such that much of the water delivered by rapid snowmelt or heavy rainfall is unable to enter the aquifer once the thin, unsaturated portion of the aquifer becomes saturated and is likely to flow overland into Meads Creek. Therefore, the potential for flooding is greatest during large storms, especially during long-term, normal spring conditions, when ground-water levels are at their seasonal maximum, and the soil unsaturated zone is thin.

The direction of ground-water movement in the valley-fill aquifer can be inferred from the potentiometric- 


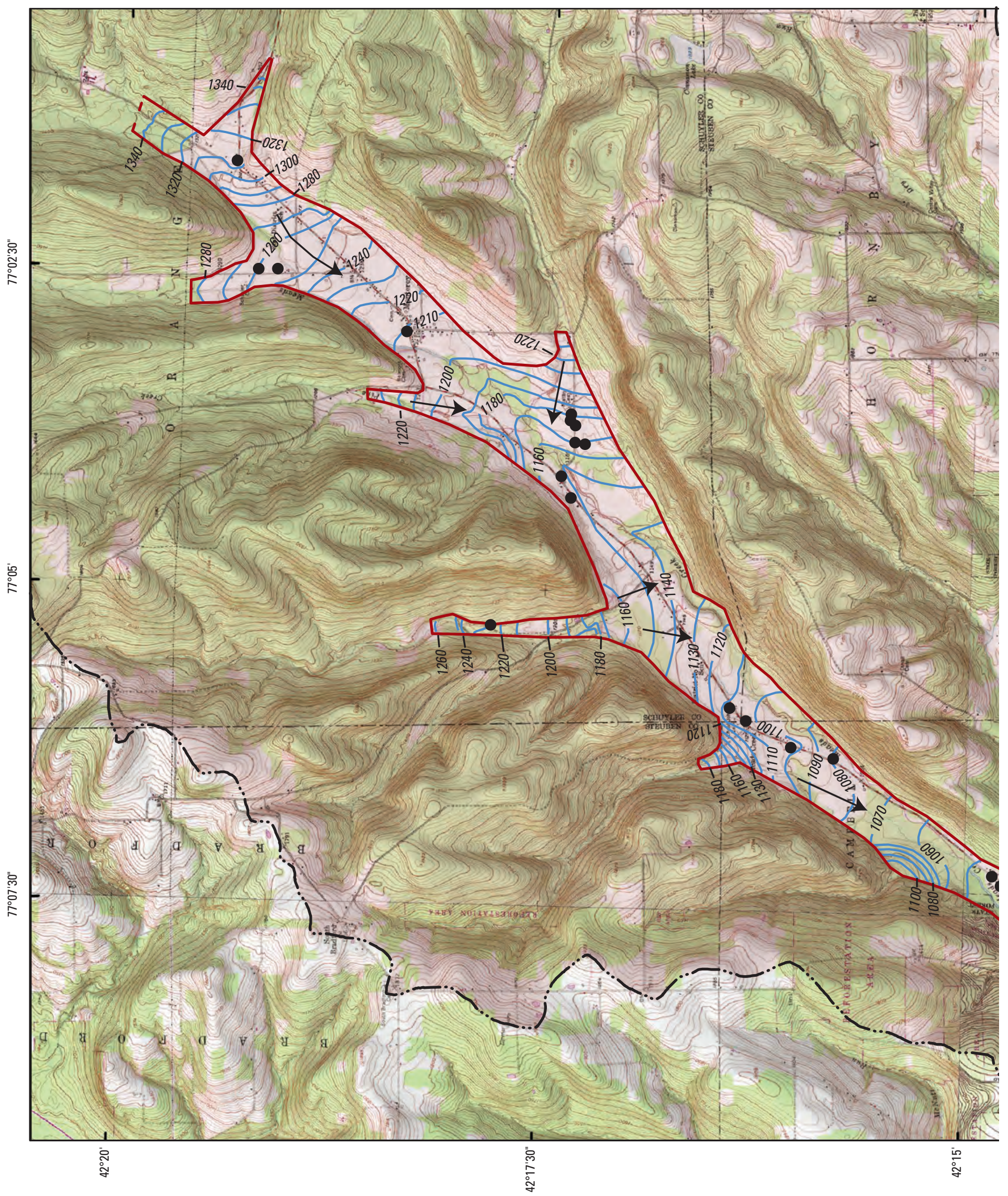




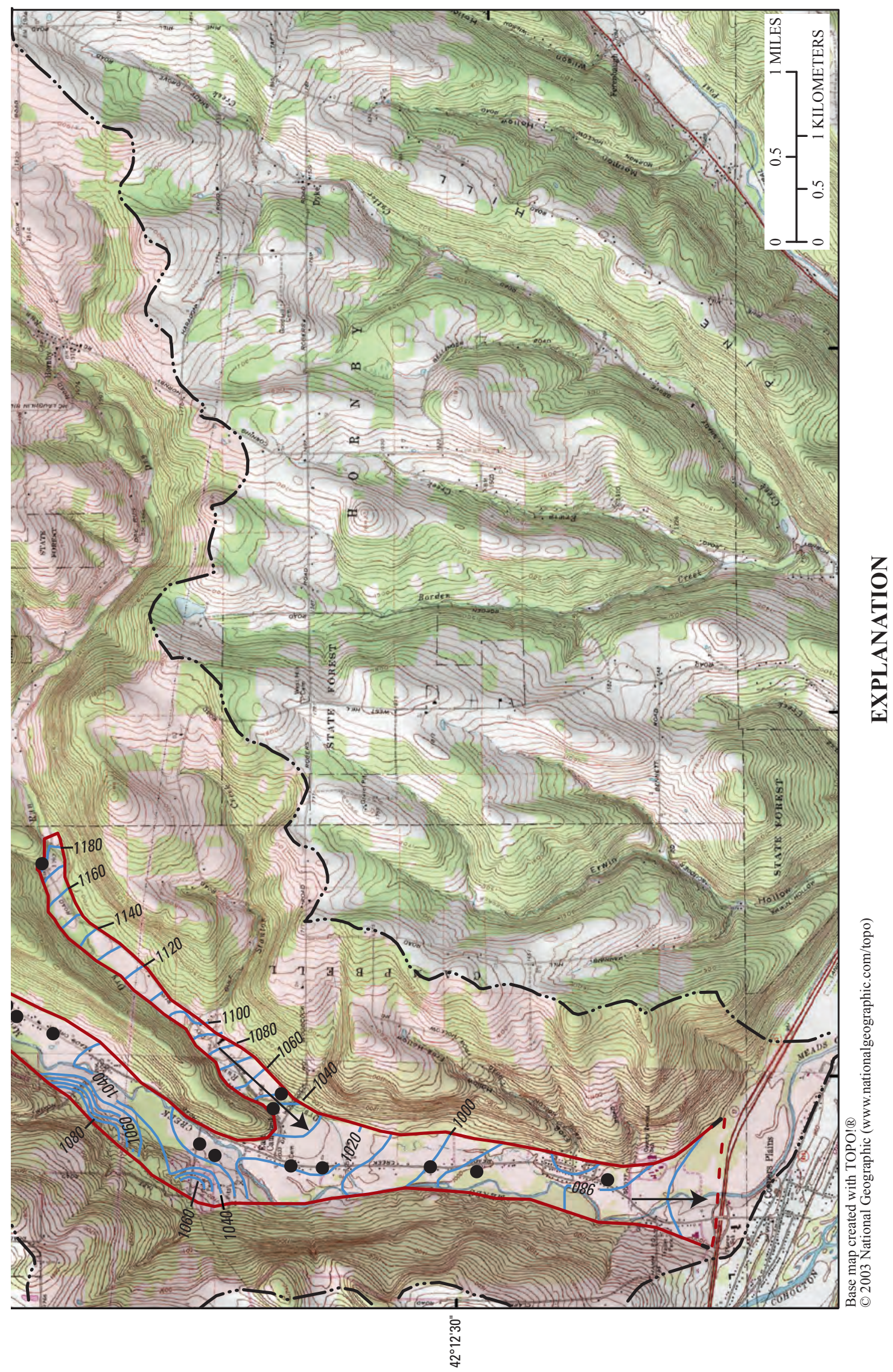

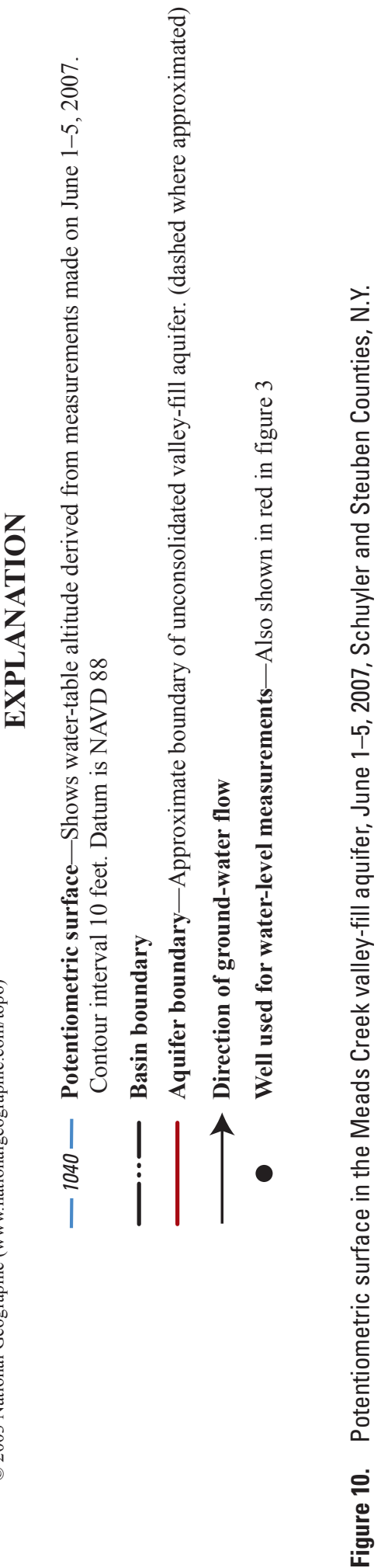


surface configuration (fig. 10). In general, ground water flows downgradient, perpendicular to potentiometricsurface contours, and from the valley edges to the stream. Potentiometric contours that bend sharply and point upslope where they cross a tributary indicate that ground water at that point is higher than the streambed and is moving into the stream; such contours are common along Meads Creek and are consistent with streamflow measurements that indicate the stream gains water along its entire length. Conversely, locations where the water table is lower than the streambed (where water moves from a stream into the aquifer) occur mainly where tributaries flow over their alluvial fans at the edge of the Meads Creek valley and are indicated by potentiometric contours that curve away from the stream channel.

Generally, the potentiometric surface of the valleyfill aquifer in the Meads Creek valley is a sloping plane that parallels the slope of the valley floor. The slope of the potentiometric surface represents changes in the hydraulic head from one area to another, and the steeper the gradient of the potentiometric surface (given a constant hydraulic conductivity) the faster the rate of ground-water flow. The hydraulic gradient in the Meads Creek valley-fill aquifer averages about $30 \mathrm{ft} / \mathrm{mi}$ or $0.006 \mathrm{ft} / \mathrm{ft}$ for the entire $12-\mathrm{mi}$ length of the valley, although it may vary locally; for example, the gradient in the southern third of the valley-from about the confluence of Dry Run south to the mouth of the valley (fig.10) - averages about $17 \mathrm{ft} / \mathrm{mi}(0.003 \mathrm{ft} / \mathrm{ft})$, only about half the $30-\mathrm{ft} / \mathrm{mi}$ gradient for the entire valley from about the confluence of Dry Run 3 mi south to the mouth of the valley.

\section{Water Budget}

A generalized water budget for the Meads Creek valleyfill aquifer was compiled from the measured and estimated amounts of recharge and discharge. The main components of aquifer recharge and discharge under average annual conditions are given in table 2; the values are generalized, however, in that some of the budget components were based on estimates, assumptions, and partly on values used in previous USGS numerical ground-water-modeling studies of similar aquifers in western and central New York.

The recharge components of the budget (table 2) are (1) direct areal recharge from precipitation on the aquifer surface, (2) recharge from upland sources including (a) streamflow loss from upland tributaries and runoff and inflow from shallow and intermediate zones in the till and bedrock and (b) unchanneled hillsides that slope toward the aquifer, and (3) ground-water inflow from deep zones in the till and bedrock along the sides and bottom of the aquifer. Discharge from the aquifer consists mainly of (1) upward flow of ground water into Meads Creek, as calculated from the streamflow measurements of April 27, 2006, and (2) deep ground-water outflow that remains in the bedrock and exits the valley at its southern end to become part of the deep regional flow system in the Cohocton River valley.

The water budget represents long-term, average annual, steady-state conditions for this aquifer and indicates that the percent contributions to total recharge from major sources are 28 percent from precipitation over the aquifer, 32 percent from losing tributaries, 38 percent from runoff and ground-water inflow from unchanneled hillsides adjacent to the valley-fill aquifer, and 2 percent from ground-water inflow from deep zones in the bedrock on the sides and bottom of the aquifer. Of the total discharge leaving the aquifer, 94 percent seeps into Meads Creek, and 6 percent is estimated to exit the aquifer as ground-water outflow through the southern end of the aquifer. The total average recharge to the aquifer in table 2, $22.6 \mathrm{ft}^{3} / \mathrm{s}$ or $14.6 \mathrm{Mgal} / \mathrm{d}$, equals the total average discharge from the aquifer because these components represent longterm, steady-state conditions. The amounts of recharge and discharge, and their percentages of the total ground-water budget, are comparable to those obtained for ground-water budgets in other, more detailed studies of valley-fill aquifers in the glaciated Northeast (Kontis and others, 2004; Miller and others, 1998; Miller, 2004; Morrissey and others, 1988).

\section{Summary and Conclusions}

The unconsolidated valley-fill aquifer in the Meads Creek valley is about $12 \mathrm{mi}$ long, averages $0.5 \mathrm{mi}$ wide, and encompasses an area of $6.2 \mathrm{mi}^{2}$. A well inventory was made to obtain data that could be used to define the hydrologic framework of the aquifer. Only a few wells had records with adequate stratigraphic information or fully penetrated the entire thickness of the valley fill; therefore, only a generalized framework of the aquifer could be defined. A seismicrefraction survey was conducted at each end of the valley to supplement the well data and to measure aquifer thickness. Results of the surveys indicate that the maximum thickness of the unconsolidated deposits in the northern end of the valley is about $125 \mathrm{ft}$, and that near the southern end is about $150 \mathrm{ft}$.

Ground-water-level measurements were made on June 1, 2 , and 5, 2007, and were used to construct a potentiometricsurface map of the aquifer to depict the directions of groundwater flow. The water levels were measured during a period of slightly above-average annual base-flow conditions, as inferred from discharge records from the nearest long-term continuously recording streamgage site (Cohocton River at Campbell, N.Y., with 90 years of record), and during a period of slightly below-average annual ground-water levels, as indicated by water-level records of the nearest long-term USGS monitoring well SB 472 (site 422445077203301) near Kanona, N.Y., 42 years of record). Mean well depth throughout the valley was $37 \mathrm{ft}$ below land surface. Water levels ranged from $1.77 \mathrm{ft}$ above land surface in one well to $23.57 \mathrm{ft}$ below land surface; the median depth was $9.27 \mathrm{ft}$ below land surface. The well records indicate that the upper 
part of the valley-fill aquifer is mostly under unconfined conditions. The potentiometric-surface gradient in the valley is generally about $30 \mathrm{ft} / \mathrm{mi}$ or $0.006 \mathrm{ft} / \mathrm{ft}$, but locally decreases to $17 \mathrm{ft} / \mathrm{mi}(0.003 \mathrm{ft} / \mathrm{ft})$ in the southern part, from about the confluence of Dry Run $3 \mathrm{mi}$ south to the mouth of the valley.

Stream-discharge measurements were made on April 27, 2006, during a period of slightly above-average annual base-flow conditions to identify gaining and losing reaches along major tributaries and the main channel of Meads Creek. Results indicate that (1) Meads Creek gained about $61 \mathrm{ft}^{3} / \mathrm{s}$ of flow, which includes ground-water seepage and tributary inflows, and (2) all measured tributaries in the northern part of the basin typically gained water - an indication that most tributaries in the northern part of the valley were not significant sources of recharge to the valley-fill aquifer during this period, and tributaries in the central and southern part of basin typically lost water and therefore were significant sources of aquifer recharge.

Aquifer recharge and discharge were calculated from streamflows measured where feasible and estimated otherwise, and the results were combined into a generalized water budget representative of average hydrologic conditions. The aquifer is recharged by (1) precipitation that falls directly on its surface, (2) upland sources that include (a) tributaries that lose water to the valley-fill aquifer where they flow over alluvial fans in the southern part of the valley before entering the main valley, and (b) unchanneled runoff and ground-water inflow from the hillsides that slope toward the aquifer, and (3) ground-water inflow from deep zones in the bedrock that enter the valley-fill aquifer along its sides and bottom. Ground water discharges from the aquifer as seepage into the main channel of Meads Creek and as outflow into the adjacent Cohocton River valley through the southern end of the valley. The total estimated aquifer recharge for the average conditions of this study was $22.6 \mathrm{ft}^{3} / \mathrm{s}$ or $14.6 \mathrm{Mgal} / \mathrm{d}$ and equals the total average discharge. The water budget is an approximation based on local measurements and estimates, and on certain general assumptions. The percentages of the total balance represented by each water-budget component are generally similar to those in water budgets calculated for other studies of similar unconsolidated aquifers in western and central New York.

Frequent flooding in the lower part of the Meads Creek valley can be attributed to a combination of several hydrologic factors, which include (1) a southward decrease of the potentiometric-surface gradient in the aquifer, especially in the southern part, which slows the flow of ground water exiting the valley; (2) a high water table and thin unsaturated zone in the southern part of the valley, which provides only minimal storage capacity and leads to overland flow during prolonged or heavy storms, and (3) the narrowing of the valley at its southern end, which restricts the outflow of ground water and stream water.

Most of the data presented here can be used as a basis for further hydraulic analyses of this stream basin. Additional information would be needed to refine the aquifer geometry and the locations and rates of aquifer recharge and discharge.
The paucity of wells, the lack of stratigraphic and water-level data, and the relatively short period of streamflow gain or loss measurements allowed only general conclusions to be made about aquifer geometry and ground-water and surfacewater exchange, and only a generalized water budget to be developed.

\section{Acknowledgments}

The authors thank the Schuyler County Soil and Water Conservation District (especially Elaine Dalrymple for her assistance in selection of wells for data collection), the Meads Creek Watershed Protection Committee, and representatives of the Soil and Water Conservation Districts and Health Departments in Schuyler and Steuben Counties for their additional help in locating wells and providing well information.

\section{References Cited}

Cadwell, D.H., 1986, Surficial geologic map of New YorkFinger Lakes sheet: New York State Museum Map and Chart Series No. 40, 1 pl., scale 1:250,000.

Darcy, H.P.G., 1856, Dètermination des lois d'ècoulement de l'eau à travers le sable in Dalmont, Victor, ed., Les Fontaines Publiques de la Ville de Dijon: Paris, p. 590-594.

Isachsen, Y.W., Landing, Ed, Lauber, J.M., Rickard, L.V., and Rogers, W.B., 1991, Geology of New York-A simplified account: New York State Museum Educational Leaflet No. 28,284 p.

Kantrowitz, I.H., 1970, Ground-water resources in the eastern Oswego River basin, New York: New York State Water Resources Commission Basin Planning Report ORB-2, $129 \mathrm{p}$.

Kontis, A.L., Randall, A.D., and Mazzaferro, D.L., 2004, Regional hydrology and simulation of flow of stratifieddrift aquifers in the glaciated northeastern United States: U.S. Geological Survey Professional Paper 1415-C, p. C1-C156, 3 pls.

Meads Creek Watershed Citizens' Committee, 2007, Meads Creek Watershed Strategic Action Plan, Final Report of Meads Creek Watershed Strategic Action Plan and Restoration Project, Elmira, N.Y., 30 p.

Mickelson, D.M., Clayton, L., Fullerton, D.S., Born, H.W., 1983, The Late Wisconsin glacial record in the United States in Wright, H.E., Jr., ed., Late Quaternary Environments of the United States, v. 1, The late Pleistocene: Minneapolis, University of Minnesota Press, p. 3-37. 
Miller, T.S., 2004, Hydrogeology and simulation of groundwater flow in a glacial-aquifer system at Cortland County, New York: U.S. Geological Survey Fact Sheet 054-03, 6 p.

Miller, T.S., Sherwood, D.A., Jeffers, P.M., and Mueller, Nancy, 1998, Hydrogeology, water quality, and simulation of ground-water flow in a glacial-aquifer system, Cortland County, New York: U.S. Geological Survey WaterResources Investigations Report 96-4255, 84 p., 5 pls.

Morrissey, D.J., Randall, A.D., and Williams, J.H., 1988, Upland runoff as a major source of recharge to stratified drift in the glaciated Northeast in Randall, A.D., ed., and others, Regional Aquifer Systems of the United StatesNortheastern Glacial Aquifers: American Water Resources Association Monograph Series, no. 11, p. 17-36.

Randall, A.D., 1996, Mean annual runoff, precipitation, and evapotranspiration in the glaciated northeastern United States, 1951-80: U.S. Geological Survey Open-File Report 96-395, 2 pls.
Rantz, S.E., and others, 1982, Measurement and computation of stream flow: U.S. Geological Survey Water-Supply Paper 2175, v. 2, 631 p.

Rickard, L.V., Isachsen, Y.W., and Fisher, D.W., 1970, Geologic Map of New York State-Finger Lakes sheet: New York State Map and Chart Series No. 15, 1:200,000, 1 sheet.

Sloto, R.A., and Crouse, M.Y., 1996, HYSEP_-A computer program for streamflow hydrograph separation and analysis: U.S. Geological Survey Water-Resources Investigations Report 96-4040, 46 p.

Stone, B.D., 1995, Progress toward higher resolution of the late Wisconsinan deglaciation sideral chronology of the New England region, 30 to $13 \mathrm{ka}$ : Geological Society of America, Abstracts with Programs, Northeastern Section, v. 26 , no. 3 , p. 84 . 
For additional information write to: New York Water Science Center U.S. Geological Survey 30 Brown Rd.

Ithaca, N.Y. 14850

Information requests:

(518) 285-5602

or visit our Web site at: http://ny.water.usgs.gov 


\section{总}

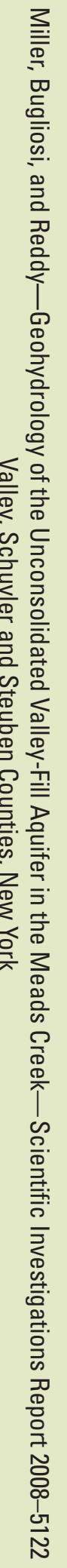

